\title{
Interplay of Regulatory T Cell and Th17 Cells during Infectious Diseases in Humans and Animals
}

\author{
Sharvan Sehrawat ${ }^{1 *}$ and Barry T. Rouse ${ }^{2}$ \\ ${ }^{1}$ Indian Institute of Science Education and Research Mohali, Mohali, Punjab, India, ${ }^{2}$ Department of Biomedical and \\ Diagnostic Sciences, College of Veterinary Medicine, The University of Tennessee, Knoxville, TN, USA
}

It is now clear that the outcome of an inflammatory process caused by infections depends on the balance of responses by several components of the immune system. Of particular relevance is the interplay between regulatory $T$ cells (Tregs) and $C D 4^{+} T$ cells that produce IL-17 (Th17 cells) during immunoinflammatory events. In addition to discussing studies done in mice to highlight some unresolved issues in the biology of these cells, we emphasize the need to include outbred animals and humans in analyses. Achieving a balance between Treg and Th17 cells responses represents a powerful approach to control events during immunity and immunopathology.

\section{OPEN ACCESS}

Edited by:

Antoine Toubert,

Paris Diderot University, France

Reviewed by:

Karen Bieback,

Medical Faculty Mannheim, Germany Federica Casiraghi,

Istituto Di Ricerche Farmacologiche Mario Negri, Italy

*Correspondence: Sharvan Sehrawat sharvan@iisermohali.ac.in

Specialty section:

This article was submitted to Alloimmunity and Transplantation, a section of the journal

Frontiers in Immunology

Received: 03 October 2016 Accepted: 09 March 2017 Published: 03 April 2017

Citation:

Sehrawat S and Rouse BT (2017) Interplay of Regulatory T Cell and Th17 Cells during Infectious Diseases

in Humans and Animals.

Front. Immunol. 8:341. doi: 10.3389/fimmu.2017.00341
Keywords: T regulatory cells, Th17 cells, cross-regulation, humans, animals, outbred population

\section{INTRODUCTION}

The realization that $\mathrm{CD} 4^{+} \mathrm{T}$ cells could be differentiated in two phenotypically separate lineages, Th1 cells that predominantly produce IFN- $\gamma$ and IL- 2 while Th 2 cells produce IL- 4 and IL-10, was elucidated by Mosmann et al. (1). The idea caught on because these cell types cross-regulated each other and this phenomenon helped in explaining many observations in inflammatory and infectious diseases. Subsequently, several additional subtypes of $\mathrm{CD} 4^{+} \mathrm{T}$ cells were discovered based on the transcription factor expressed, their cytokine profile and functions $(2,3)$. Of particular relevance was the discovery that some $\mathrm{CD} 4^{+} \mathrm{T}$ cells play a regulatory role and helped to constrain the effector function of other cell types. We currently recognize at least four $\mathrm{CD} 4^{+} \mathrm{T}$ cell subsets which largely play an effector function (Th1, Th2, Th9, and Th17) and another subset $\mathrm{T}$ follicular helper cell $\left(\mathrm{T}_{\mathrm{FH}}\right)$ which plays a major role during immune induction (4). This review focuses largely on the cross play between regulatory $\mathrm{T}$ cells (Tregs) and Th17 cells since these two subsets often subserve opposite roles during inflammatory processes. Th17 cells are recognized as one of the predominant proinflammatory cell types and produce IL-17 to help attract other innate immune cells such as macrophages and neutrophils to further aggravate chronic inflammation. The transcription factor RAR-related orphan receptor (ROR)- $\gamma$ t regulates the speciation program of Th 17 cells. Tregs on the other hand act to regulate the differentiation and activity of Th17 cells. In fact, several lines of evidence demonstrate that Treg and Th17 cells exhibit some key shared differentiation pathways (Figure 1). Thus, both cell types require TGF- $\beta$ and IL-2 for their differentiation and are predominantly present in the gut to maintain homeostasis (5). Both Treg and Th17 cells exhibit specificity toward commensal-derived antigens or self-antigens and their speciation transcriptional program shows direct interaction (5). Of the two major classes of antigen-presenting cells (APCs) in the gut, dendritic cells (DCs) are known to promote Th17 cell responses while macrophages promote Treg responses (6). Treg and Th17 cells were shown to predominantly maintain gut homeostasis but their interplay in other 


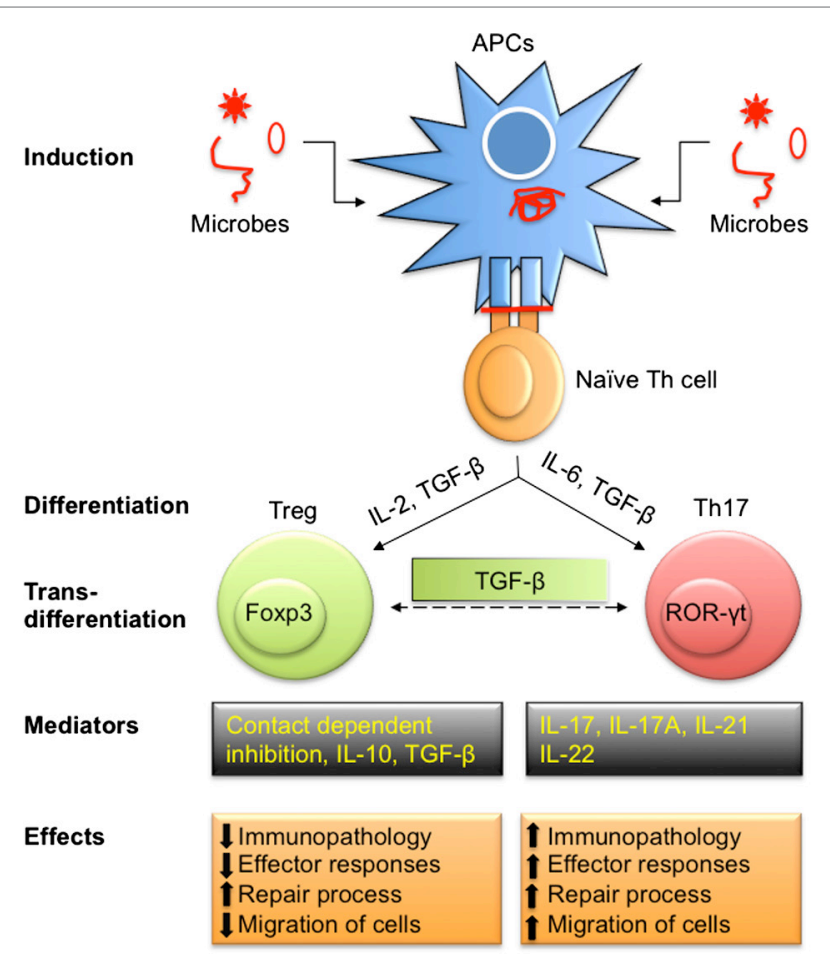

Outcome

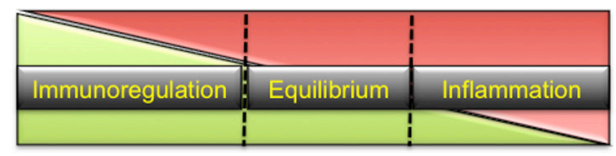

FIGURE 1 | Differentiation of T regulatory cells (Tregs) and Th17 to effect immunity and immunopathology during infections. Antigenpresenting cells (APCs) either by direct infection or by exogenously taking up antigens process polypeptides intracellularly to generate peptides. These peptides are loaded onto class II MHC molecules and presented on their surface to activate naïve Th cells. Depending upon the affinity of TCR to recognize processed peptides and the microenvironment in which such interactions take place, Th cells are polarized into pTreg and Th17 cells to maintain homeostasis. Treg and Th17 cells can also transdifferentiate depending on intrinsic as well as some extrinsic factors such as local concentration of TGF- $\beta$. Predominant products of Treg include IL-10, IL-35, and TGF- $\beta$ in addition to membrane-expressed molecules while Th17 cells secrete IL-17, IL-21, IL-22, and other cytokines. Tregs cause immunoregulation while Th17 serve as proinflammatory cells during disease progression. Treg and Th17 leads to differential outcome ranging from dominant regulatory to stimulatory activity while a fine balance ensures homeostasis.

diseases that include those caused by infections is beginning to be appreciated.

The idea that $\mathrm{T}$ cells could suppress the function of other cells was popularized by Gershon and Kondo (7). The cells were called suppressor cells, but since there were no reliable means of identifying them, they soon fell into disrepute. Resurrection and respectability for Treg came some two decades later by the work performed by the Sakaguchi et al. and Suri-Payer et al. who had discovered a reliable way of distinguishing Treg from other cell types and also demonstrated their regulatory effects (8-10). Sakaguchi et al. and Thornton and Shevach demonstrated that
$5-10 \%$ of $\mathrm{T}$ helper (Th) cells that expressed the high affinity IL-2 receptor alpha $(\alpha)$ chain (CD25) were present in naïve mice and were able to suppress the proliferation of those cells that did not similarly express this molecule $(9,11)$. The idea of Treg's existence helped in explaining many unsolved mysteries in immunobiology such as how tolerance is maintained and the variable outcome of autoimmune and infectious diseases is effected (12-14). The canonical transcription factor Fork head box protein 3 (Foxp3), responsible for controlling the function of Treg and acting as their identifier, was discovered in 2001 (15-17). Whereas Foxp $3^{+}$Tregs are perhaps the most prominent regulatory cells, other cell types have been observed to mediate regulatory effects alongside or alternatively to Foxp $3^{+}$Treg. These many alternative regulators include $\operatorname{Tr} 1$ cells, Th3 cells, $\mathrm{CD}^{+}$Treg, double negative $\mathrm{CD}^{+} \mathrm{T}$ cells, gamma delta $(\gamma \delta)$ $\mathrm{T}$ cells, natural killer T cells, regulatory B cells, myeloid-derived suppressor cells, and perhaps others.

A great majority of our understanding of how the immune system works comes from studies performed in inbred mice housed in controlled environment. Our ultimate objective, however, is to understand the workings of the immune system and to apply the wisdom to manipulate the outcome of events in humans and other animals. There is still a gap in our knowledge regarding what happens in humans and outbred non-rodents and this issue is elaborated in this review. We also discuss unresolved issues in the biology as well as pathophysiology of Treg and Th17 cells during infectious diseases.

\section{BIOLOGY OF TREG AND Th17 CELLS}

The expression of the transcription factors Foxp3 and ROR- $\gamma \mathrm{t}$ defines Treg and Th17 cells, respectively. Foxp3 is critically involved in the differentiation and function of Treg. Foxp3 does so by directly binding to DNA to be transcribed and in so doing regulates the transcription of more than thousand genes many of which are involved in $\mathrm{T}$ cell activation. Some of the Treg-specific genes directly targeted by Foxp3 are Il2ra (CD25), Tnfrsf18 (GITR), Nrp1 (neuropillin-1), and Ccr4 among others (18-20). Foxp3 could also influence gene expression indirectly by recruiting epigenetic modifiers such as histone deacetylases (HDAC1, 2, and 3) in the complex (21). Many genes that include Il2 are downregulated by HDACs activity. As newer mechanistic insights are emerging, clearly there is need of more studies to better define the role of Foxp3 in programming Treg and in fact different functions could be attributed to its different domains. Similarly, Foxp3 regulates the expression of some chemokine receptors suggesting that it may also control the homing of Treg. The latter effect has not received much attention and needs to be understood in greater detail. This is because immunosuppression at inflammatory sites is one of the most desirable outcomes of cell-based immunotherapies.

Tregs are broadly divided into thymically derived regulatory $\mathrm{T}$ cells (tTregs) and those that are induced in the periphery (pTregs). pTregs are usually more plastic than tTregs (22). Nrp1 may act as the distinguishing marker between $t$ Treg $(+)$ and pTreg (-) (23-25). Tregs in the thymus develop after 3 days of birth and a thymectomy at 3 days of birth abrogates Treg responses 
leading to multiorgan autoimmune inflammatory diseases (26). However, some Treg that specifically home to select lymphoid organs can be detected in 3-day-old thymectomized mice (27). Therefore, it could be that the kinetics of Treg generation in the thymus is also linked to their differential homing pattern. As and when growing animals are exposed to different environmental conditions that include feed and habitation, the homing properties, functionality, and repertoire of Treg may be refined further to maintain homeostasis at different locations.

For the induction of $\mathrm{T}$ cell responses that include Treg, three signals comprising MHC-peptide-TCR, engagement of co-stimulatory/inhibitory molecule, and cytokines in milieu are required $(28,29)$. Issues such as the strength and the nature of inducing signals and the subsequent formation of either plastic or stable Treg are beginning to be investigated (30). Low to intermediate affinity interactions between the TCR expressed by developing $\mathrm{T}$ cells and peptides-MHC class II complexes in thymus are considered as one of the critical drivers of Treg differentiation (28). Contrary to what was considered as a paradigm that both $\alpha$ and $\beta$ chains of the TCR are involved in peptide binding (31), a recent study demonstrated that only the $\beta$ chain of TCR along with its framework regions contributed to peptide binding in $\operatorname{Tr} 1$ cells and thereby making it a very low affinity interaction $(32,33)$. However, one wonders how such a weakly interacting TCR ensures survivability of T cells during the thymic selection process. Whether or not TCRs of different types of Treg also display a similar orientation and affinity remains unexplored.

The affinity with which TCRs of Th17 cells recognize peptides has not been extensively explored. Only a few studies have demonstrated that TCRs of Th17 cells might exhibit a low affinity (34). High affinity interactions in fact might be counterproductive for gut health, a site so heavily infested by microbes. Thus, in healthy individuals a unique tripartite interaction among gut microbiota, Treg, and Th17 cells may be required to maintain gut homeostasis (35). Conceivably, Th17 cells act to control the excessive growth of microbes in the gut while Tregs regulate Th17 cell responses. Whether Th17 cells exhibit differential TCR specificity or affinity toward antigens and how it affects their pathogenicity is worth investigating and could indeed help identify Th17 cell subsets with different functions. Some studies have supported a similar idea that Th17 cells could indeed exist in different subtypes (36-38). Accordingly, a local intracellular concentration of saturated fatty acids (SFA) compared to polyunsaturated fatty acids (PUFA) favored more pathogenic Th17 cell formation (38). Differential accumulation of SFA or PUFA and their binding to intracellularly expressed CD5L led to the generation of Th17 exhibiting differential pathogenicity (38).

The stimulating antigens for Treg and perhaps for Th17 cells could also be generated during an ongoing inflammatory response caused by autoimmune diseases or infections. To support this notion, a few studies have demonstrated that Tregs isolated from draining LNs are more active and better suppressors as compared to those isolated from distal LNs (39-42). In draining LNs, APCs home from local sites and predominantly sample antigens released from these areas. This provides ample stimulation for Treg to remain better suppressors.
TGF- $\beta$ is a critical cytokine required at least in vitro for inducing the regulatory phenotype in T cells. Depending on the concentration, context, and condition, TGF- $\beta$ helps skew responses toward Treg or Th17 cells $(43,44)$. Thus, a greater concentration of TGF- $\beta$ may be conducive for a Treg response while a lower concentration particularly in the presence of other inflammatory cytokines such as IL-6 and IL-21 could preferentially promote Th17 responses (45). In fact, some pathogens either encode for the homologs of TGF- $\beta$ or help activate latent TGF- $\beta$ and this may be responsible for differential proinflammatory or regulatory responses (46). Whether or not TGF- $\beta$ is critical for Treg generation in the thymic environment was investigated in the absence of TGF- $\beta$ signaling using complete knockout or T cell specific TGF $\beta$ RII knock out mice (47-49). These studies revealed that an absence of TGF- $\beta$ signaling only affected the peripheral pool of Treg and not their thymic generation (47). It could also suggest that Treg that develop in the thymus halt their proliferation and remain quiescent until they home to the periphery. The reduced proliferation of Treg in the thymus could be the consequence of limited antigen availability and the presence of abundant TGF- $\beta$, both of which could serve to induce slow proliferation of Treg (48). The thymic microenvironment could indeed provide copious amount of TGF- $\beta$ for Treg differentiation or maintenance because of an ongoing process of apoptosis and disposal of such cells by phagocytic activity of DCs and macrophages (49). Another signal that has been implicated in Treg generation is retinoic acid, a metabolite of vitamin A (50). The expression of TGF- $\beta$ and retinoic acid has also been demonstrated in the thymus supporting the notion that these induction pathways either alone or cooperatively could help thymic Treg generation (51-53).

IL-2 signaling is critically involved in Treg as well as Th17 cell differentiation. IL-2 is consumed preferentially by Treg since they express high affinity IL-2 receptors (54). IL-2 also acts to stabilize Foxp 3 induced by TGF- $\beta(30,55)$. Treg are supposed to dampen inflammation where a mix of both pro- and anti-inflammatory cytokines constitutes the microenvironment. Therefore, the functionality of Treg needs to be evaluated in the presence of relative abundance of different cytokines. TGF- $\beta$ and IL-2, if present in an environment along with other proinflammatory cytokines such as IL-1 $\beta$, IL-6, IL-21, or IL-23, facilitate Th17 differentiation at the expense of Treg (56). It is worth investigating how ROR- $\gamma \mathrm{t}$ in Th17 cells actually promotes their programming. Thus, whether or not the transcription factor ROR- $\gamma \mathrm{t}$ in Th17 cells actually binds in the promoter region of IL-17 to modulate its expression has not been shown experimentally. However, a putative binding site of ROR- $\gamma$ t in IL-17 promoter has been predicted (57). Similarly, any naturally existing endogenous ligands for ROR- $\gamma \mathrm{t}$ is yet to be identified. The induction kinetics of such ligands during infection could provide better insights into the differentiation of Th17 cells during an ongoing immune response and provide potential targets to block a pathogenic response. One such example is binding of an artificial ligand digoxin to ROR- $\gamma \mathrm{t}$ which acts to diminish IL-17 production (58). The factors shown to favor and antagonize Treg and Th17 cells in different species are summarized in Table 1. In a subsequent section, we highlight technological advances that facilitated Treg or Th17 cell response investigations 
TABLE 1 | A summary of positive and negative regulators of regulatory $\mathrm{T}$ cell (Treg) and Th17 cell response in different species.

\begin{tabular}{|c|c|c|c|c|}
\hline \multirow[t]{2}{*}{ Species } & \multicolumn{2}{|c|}{ Tregs } & \multicolumn{2}{|c|}{$\begin{array}{l}\mathrm{CD4}^{+} \mathrm{T} \text { cells that produce } \\
\text { IL-17 }\end{array}$} \\
\hline & $\begin{array}{l}\text { Promoting } \\
\text { factors }\end{array}$ & $\begin{array}{l}\text { Inhibiting } \\
\text { factors }\end{array}$ & $\begin{array}{l}\text { Promoting } \\
\text { factors }\end{array}$ & $\begin{array}{l}\text { Inhibiting } \\
\text { factors }\end{array}$ \\
\hline \multirow[t]{6}{*}{ Mouse } & IL-2 & IL-6 & $\mathrm{IL}-6$ & $\begin{array}{l}\text { TGF- } \beta \text { (high } \\
\text { concentration) }\end{array}$ \\
\hline & TGF- $\beta$ & TNF- $\alpha$ & $\begin{array}{l}\text { TGF- } \beta \text { (low } \\
\text { concentration) }\end{array}$ & $\mathrm{IL}-2$ \\
\hline & $\mathrm{IL}-10$ & $\| \mathrm{L}-1 \beta$ & $\mathrm{IL}-21$ & $\mathrm{IL}-4$ \\
\hline & Lower affinity of & & $\mathrm{IL}-23$ & IL-12 \\
\hline & TCR & & $\begin{array}{l}\text { Saturated fatty } \\
\text { acids }\end{array}$ & $\mathrm{IFN}-\gamma$ \\
\hline & & & $\mathrm{IL}-1 \beta$ & $\begin{array}{l}\text { Polyunsaturated } \\
\text { fatty acids } \\
\text { Estradiol }\end{array}$ \\
\hline \multirow[t]{7}{*}{ Human } & $\begin{array}{l}\text { Antigen or } \\
\text { mitogen }\end{array}$ & IL-6 & IL-6 & TGF- $\beta$ \\
\hline & $\mathrm{IL}-2$ & IL-21 & $\begin{array}{l}\text { TGF- } \beta \text { (low } \\
\text { concentrated) }\end{array}$ & $\mathrm{IL}-4$ \\
\hline & TGF- $\beta$ & IL-23 & $\mathrm{IL}-21$ & IL-12 \\
\hline & & IL-17 & IL-23 & $\mathrm{IFN}-\gamma$ \\
\hline & & TNF- $\alpha$ & & \\
\hline & & IL-1 $\beta$ & & \\
\hline & & RANTES & & \\
\hline \multirow{4}{*}{$\begin{array}{l}\text { Canine } \\
\text { (dogs) }\end{array}$} & Con-A & IL-6 & IL-6 & TGF- $\beta$ \\
\hline & IL-2 & $\mathrm{IL}-1 \beta$ & IL-1 $1 \beta$ & \\
\hline & TGF- $\beta$ & & TFG- $\beta$ & \\
\hline & $\mathrm{IL}-10$ & & & \\
\hline \multirow{4}{*}{$\begin{array}{l}\text { Feline } \\
\text { (cats) }\end{array}$} & Mitogens & IL-6 & $\mathbb{I L}-1 \beta$ & TGF- $\beta$ \\
\hline & LPS and flagellin & $\| \mathrm{L}-1 \beta$ & IL-6 & IL-10 \\
\hline & $\mathrm{IL}-2$ & & TGF- $\beta$ & \\
\hline & & & IL-21 & \\
\hline Bovine & $\begin{array}{l}\text { Antigen or } \\
\text { mitogens along } \\
\text { with IL-10, TGF- } \beta\end{array}$ & IL-6 & IL-23 & $\begin{array}{l}\text { Progesterone, } \\
\text { IFN- } \gamma\end{array}$ \\
\hline
\end{tabular}

as well as their interplay and also make some comments about their potential therapeutic value.

\section{HOW DO WE STUDY THE FUNCTION AND PHENOTYPE OF TREG AND Th17 CELLS?}

A summary of the key technological advancements that has facilitated studies involving phenotype and function of Treg and Th17 cells is provided in Figure 2. One of the initial identifiers of Treg in naïve mice was surface expression of CD25 (IL-2R $\alpha$ chain) and this served as a marker to facilitate their isolation and characterization (10). The discovery of the bona fide transcription factor Foxp3 advanced the field since it is distinctive of Treg and separates them from non-Treg during ongoing infections. Foxp3 not only confers Treg with their regulatory function but also is used for monitoring Treg responses during disease progression to serve as a prognostic biomarker $(15,16,59-62)$. As Foxp3 is expressed intracellulary, its detection requires cells to be permeabilized, which renders them dysfunctional, and hence limits utility. The issue was addressed in inbred mice by Bettelli et al. and Fontenot et al. who constructed a Foxp3-GFP knock-in mouse so that live cells could be recovered based on GFP positivity $(63,64)$. This model also allowed studying migration and localization of Treg during infections (65-67). Other transgenic mouse models such as Foxp3-diphtheria toxin receptor (DTR) also helped advance our understanding of the function and pathophysiology of Treg especially during ongoing infections and immune activation. The DTR is not naturally present in mice and, therefore, a selective depletion of Treg could be achieved by injecting minimal dose of diphtheria toxin $(13,66,68,69)$. Many studies employed this model to study the role of Treg during different stages of an ongoing infection or autoimmune disease $(66,70)$.

A confounding problem, however, complicated matters since it was realized that Treg might lose their expression of Foxp3 as well as their regulatory function. Moreover, such cells could even take on the function of effector T cells (4). This phenomenon is usually referred to as plasticity or the transdifferentiation. This can be investigated with the availability of so-called fate mapping mice $(77,78)$. Such animals are constructed in a way that desirable gene products such as Foxp3 or IL-17 are driving Cre recombinase. Crossing these animals with reporter floxed mice having a transgene for fluorescent protein generated fate-mapping mice to address plasticity issues during infections and other inflammatory situations $(77,79)$. Whether or not proinflammatory cells producing IL-17 could also become regulatory at a later time, triple fate mapping mice have now been created (77). Using these animals, it was demonstrated that Th17 cells could transdifferentiate into $\operatorname{Tr} 1$ cells in a model of parasite induced inflammatory disease (77). Thus, fate-mapping mice have become a valuable model to follow the functional changes of $\mathrm{T}$ cell subsets in different situations. The method of generation such as inducible vs constitutive expression of transgene/reporter, number of copies inserted, and the expression of products under non-endogenous promoters could, however, impact on the overall utility of such animal models (80). Whether or not Treg plasticity occurs in humans has been difficult to quantify and co-staining for different markers followed by multicolor flow cytometry represents one surrogate way to measure it. In order to generate phenotypically stable regulatory $\mathrm{T}$ cells, approaches that modify epigenetic architecture are used. For example, epigenetic modifiers such as HDACs or DNA methyltransferases (DNMTs) inhibitors are used. The use of azacytidine that inhibits DNMTs activity ameliorated herpes simplex virus 1 (HSV-1) induced ocular inflammatory lesion and enhanced Treg responses (81).

In order to gain insights into the functioning of Treg or Teffectors in lymphoid organs or in inflammatory tissues, cells need to be visualized in vivo. This could be achieved using two photon intravital microscopy but its accessibility is limited $(82,83)$. Many observations obtained using inbred strains may not translate to outbred populations for reasons such as the representation of limited MHC polymorphism in former animals. In addition, spontaneous exposures of feral animals to multiple antigens as compared to those that are housed in clean facilities may also yield confounding conclusions. That a dirty environment can make a difference is being emphasized and may include differential migration pattern of immune cells as was shown for $\mathrm{CD}^{+} \mathrm{T}$ cells $(84,85)$. This led to differential outcome during a subsequent viral infection (84). There is no reason to believe that 


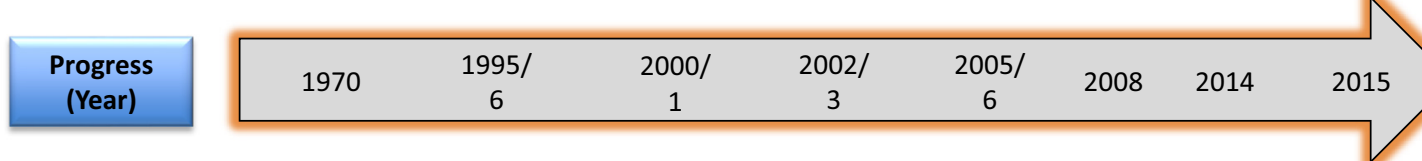

Regulatory T cells

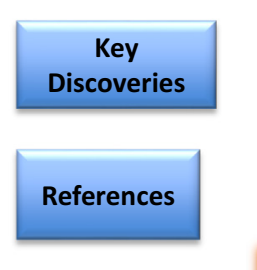

\begin{tabular}{|c|c|c|c|c|c|c|c|}
\hline & & Re: & latory & cells & & & \\
\hline $\begin{array}{c}\text { Suppressor } \\
\text { Cells }\end{array}$ & $\begin{array}{c}\mathrm{CD}^{+} \\
\text {Regulatory } \\
\text { T cells }\end{array}$ & TF Foxp3 & $\begin{array}{l}\text { Treg \& } \\
\text { Infection }\end{array}$ & $\begin{array}{l}\text { Foxp3- } \\
\text { GFP KI }\end{array}$ & $\begin{array}{l}\text { Foxp3- } \\
\text { DTR }\end{array}$ & $\begin{array}{c}\text { Fate } \\
\text { Mapping } \\
\text { mice }\end{array}$ & $\begin{array}{c}\text { Tripple } \\
\text { FMM }\end{array}$ \\
\hline
\end{tabular}

(7)

(9)

(15)

(71)

$(64,63)$

$(66,68)$

(79)

(77)

\section{Th17 cells}

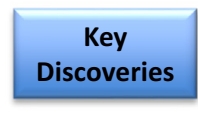

References

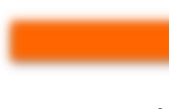

Tripple

FMM cross play with Treg

(64)

FIGURE 2 | Timeline in brief for methodological advances for investigating regulatory T cell (Treg) and Th17 responses in animals (TF, transcription factor; KI, knock-in-mice; DTR, diphtheria toxin receptor; FMM, fate mapping mice) (71-76).

such a situation would not exist for Th subsets and other types of infections.

One model that could be valuable to address such issues is the zebrafish (Danio rerio) (86). The model could be particularly valuable to study cellular interactions due to its anatomical visual transparency. For investigating Treg and Th17 responses in zebrafish, the genes encoding for transcription factors Foxp3 and ROR- $\gamma$ t have been cloned successfully (87). The immune cells and molecules known to exist in vertebrates critical for adaptive immunity are also present in zebrafish (88). Procedures such as transgenesis, nuclear reprogramming, and gene function disruption can be performed with ease in these animals as compared to mice (89-92). Therefore, rather than demonstrating immunological events with select few lines, multiple lines of zebrafish can be generated and used $(93,94)$. Moreover, the zebrafish is an excellent model for tracing some infectious diseases such as tuberculosis. The granuloma formed by mycobacterial infection in zebrafish exhibits similar histological and pathological features as are evident in $M t b$ infected human granuloma lesions $(95,96)$. The zebrafish model could surely empower immunologists to visualize the cross regulation of Treg and Th17 cells in pathophysiology of diseases.

The functionality of Treg and Th17 cells can be measured by various in vitro assays and in vivo adoptive transfer approaches. In vitro functional assays include isolating and co-culturing Treg with identifiable non-Treg to measure the functionality $(11,97)$. Whether or not suppressive activity is contact dependent can be established using trans well assays (11). The responding cells used for suppressive assays can either be stimulated in a polyclonal manner or by antigen pulsed APCs (98).

\section{COMPARISON OF TREG AND Th17 RESPONSE IN HUMANS, RODENTS, AND NON-RODENT ANIMALS}

Although there are considerable similarities in the function and phenotype of Treg as well as Th17 cells isolated from mice and humans, differences are also evident. Isoforms of Foxp3 that lack exon 2 or exon 7 exist in human, but not in mice suggesting that the differentiation pathways for Treg in humans and mice may differ (99). Stimulated CD $4^{+} \mathrm{CD} 25^{-} \mathrm{T}$ cells in the presence of IL-2 and TGF- $\beta$, express Foxp3 and IL- 2 acts to stabilize the expression (30). In the absence of TGF- $\beta$, Foxp 3 could be expressed transiently in stimulated Foxp $3^{-}$T cells isolated from humans and to a lesser extent in mice but human cells express latent TGF- $\beta$ on their surface (100-102). Reactive oxygen species are abundantly present during the initial stages of inflammation and can activate latent TGF- $\beta$ to make it available for further differentiation into either Treg or Th17 cells. The stages of human Treg generation when TGF- $\beta$ and IL- 2 are critically involved are not yet clearly identified and most studies have concluded that these cytokines dominantly help stabilize Foxp3 expression (49). Varying degrees of epigenetic changes in the Foxp3 locus of human and mouse Treg have been observed $(103,104)$. Thus, the Foxp3 locus in humans is methylated to a greater extent as compared to that in mice suggesting human Treg take longer to adopt a phenotype 
similar to that of mouse Treg (30). The identification markers used for distinguishing human and mouse Treg also display discordance. Thus, even Foxp3 cannot be used for unambiguously defining Treg in humans, unlike in mice (105). Cells expressing sustained Foxp3 expression, however, are considered as suppressive cells. The recently described marker Nrp1 that distinguishes mouse tTreg from pTreg does not faithfully identify one subset or the other in humans (106).

IL- 6 and TGF- $\beta$ play a non-redundant role in the generation of mouse Th17, but this may not be true for human Th17 cell generation (107). IL-1 $\beta$, TNF- $\alpha$, and IL-23 are all effective inducers of ROR- $\gamma$ t in differentiating human Th17 cells (108). TGF- $\beta$ may be dispensable for Th17 cell generation in humans but not in mice (101). The requirement of factors for differentiation of human Th17 cells, however, needs to be cautiously interpreted. Thus, most studies focusing on differentiation of human Th17 cells were performed using peripheral blood cells, and donors are expected to have an exposure to one or more antigens. Therefore, the starting population may not be naïve. Cells are more likely to be naïve when isolated from cord blood and for such cells to differentiate into Th17, TGF- $\beta$ seems to be critically involved (107). Therefore, differentiation and transdifferentiation of human Th cells need to be fully understood for both naïve and committed cells in order to manipulate Th17 cell responses.

Regulatory T cells and to a lesser extent Th17 cells have been described to exist in most non-rodent animals as well. However, as is described for humans and mice, a mutation in Foxp3 and any subsequent phenotypic effect has not been described in other animals. This could be because of the rarity of such genetic disorders. Anti-human or mouse Foxp3 monoclonal antibodies that crossreact with xenogeneic Foxp3 molecule are used for immunophenotyping Treg in other animal species. Various domains of Foxp3 are conserved across different species and hence show appreciable cross reactivity (109). Foxp3 specific monoclonal antibodies were produced for some non-rodents such as cats and bovines to detect and measure Treg responses (110-112). In cats, an alternative splice variant of Foxp3 lacking exon 2 also exists, an observation similarly recorded for human Foxp3 (99). Surprisingly, when wild type and the variant lacking in exon 2 were expressed in a cell, the suppressive activity was enhanced, as compared a single version expressing cells suggesting a critical role of exon 2 in activity of Treg (111). Cytokines shown to promote Th17 responses in cats are IL- $1 \beta$, IL- 6 , TGF- $\beta$, and IL-21 (113). Foxp $3^{+}$Treg have been demonstrated in animals that include pigs, cows, sheep, goat, horses, baboon, macaque, chimpanzee, harbor seals, and walrus (109). The Foxp3 expression could be induced in CD4 ${ }^{+}$as well as $\mathrm{CD}^{+} \mathrm{T}$ cells isolated from lymph node of healthy dogs that were stimulated with Con-A (114). A subset of cells that express Foxp3 at intermediate level, but not Foxp3 high cells, also expressed IFN$\gamma$ suggesting a plastic nature of such stimulated Treg as well as their tendency to acquire an effector phenotype (115). This could also means that those cells that express optimal level of Foxp 3 are more stable as compared to those expressing it to a lower level and the latter cells are not fully committed to Treg phenotype. $\mathrm{CD}^{+} \mathrm{T}$ cells isolated from PBMCs could be efficiently polarized into Th17 cells using a poly-specific stimulator con-A and a combination of cytokines that include IL- 6 , IL- $1 \beta$, and TGF- $\beta$
(116). Foxp $3^{+}$Tregs in other species were also described. In fact, suppressor cells in domestic animals were described even before $\mathrm{CD} 25^{+} \mathrm{CD} 4^{+} \mathrm{T}$ cells description in mice. In most of these studies, PBMCs stimulated with con-A for a few days acquired suppressive activity toward autologous and allogeneic blood cells (117), but phenotypic markers of these suppressor cells were not described. More recently, Foxp 3 was detected not only in bovines $\alpha \beta$-T cells but also in a small proportion of $\gamma \delta$-T cells that were stimulated with Con-A $(118,119)$. In fact, a recent report suggested that in ruminants that includes bovines, $\gamma \delta$-T cells predominantly play a regulatory role by producing copious amounts of IL-10 and the contribution of $\mathrm{CD} 4{ }^{+} \mathrm{CD} 25^{+}$Foxp $3^{+} \mathrm{T}$ cells as regulatory cells is minimal (120). In small ruminants that include sheep and goats, Foxp3 expression was not only limited to $\mathrm{CD} 4^{+} \mathrm{T}$ cells, but was also detectable in other cells such as $\mathrm{CD} 4^{+} \mathrm{CD} 8^{+} \mathrm{T}$ cells, CD4 $\mathrm{CD}^{+} \mathrm{T}$ cells, as well as double negative $\mathrm{CD}^{+} \mathrm{T}$ cells (109). The proportion of non-CD4 ${ }^{+} \mathrm{T}$ cells showing Foxp3 expression was variable however. The recorded variation in Treg responses could be attributed to a lack of appropriate reagents, pathophysiological condition of animals, and accessibility to tissues samples for analysis. Animals that are also used for meat purpose, the analyses could be performed using peripheral blood as well as accessing lymphoid organs from slaughtered animals.

In summary, Treg and Th17 cells are likely to be present in most vertebrate species as these cells are thought to have coevolved (5). The contribution of Th17 cells and the cytokine IL-17 in the pathogenesis of some infectious diseases in some of the non-rodent animals has been described $(116,121)$. However, most of these studies are observational, and cells were isolated from peripheral blood samples only.

\section{INTERCONVERSION OF TREG AND Th17 CELLS}

Does plasticity of Th subsets confer any advantage to the host? The answer probably is in the affirmative. Thus, thymic regression with age limits $\mathrm{T}$ cell precursor frequency and the interconverting ability of different Th subsets could provide a facility for the generation of an appropriate helper $\mathrm{T}$ cell response required for an efficient adaptive immunity. The cytokines present in the milieu dictate the phenotype of cell upon differentiation, which is well appreciated (122). Functional alteration can include a loss of a useful function, gain of an undesirable activity, or a change in cell location from the site where they normally function. Naïve nonTreg $\left(\mathrm{CD}^{+}{ }^{+}\right.$Foxp $\left.3^{-}\right)$are converted into Treg $\left(\mathrm{CD} 4^{+} \mathrm{Foxp}^{+}\right)$when stimulated in the presence of IL- 2 and TGF- $\beta$ (11). Similarly, the forced expression of Foxp 3 converted conventional T cells into Treg that exhibited a suppressive activity (59). Treg may lose expression of Foxp3 but may not necessarily undergo functional changes (123). Alteration in a cell location is usually explained by differential expression of homing molecules and this relocation can also explain functional changes in some instances $(40,42)$. Relocation effects may help explain changes in Treg activity during different phases of an inflammatory response. In fact, during an acute inflammatory response, the number of Foxp $3^{+}$Treg in draining lymph node is reduced dramatically while their number 
increased in distal lymph nodes. This could mean that Treg prefer to stay in a non-inflammatory environment conceivably by modulating their homing receptors. This may also mean that Treg are more efficient in regulating responses that are milder in nature. Alternatively, those cells that reside in the most severe inflammatory environments and still retain the phenotype are more resilient and less likely to become non-Treg. All these issues have yet to be addressed adequately.

Among factors responsible for conferring stability and limiting, plasticity is the continuous availability of cytokines such as IL-2 (124). Treg that are deprived of IL-2 and potentially other cytokines are more inclined to change their phenotype (125). At a molecular level, this outcome can be explained in terms of epigenetic alterations in the conserved non-coding sequences (CNS) of Foxp 3 gene (126). Some have advocated that the subsets of Treg that are more plastic are those at an intermediate stage of their differentiation $(122,126)$. Such cells may eventually fail to establish their complete epigenetic architecture, an effect that can be influenced by the microenvironment (122). One of the most studied epigenetic modifications that is known to influence the stability of Treg is methylation of CpG islands in the CNS2 of Foxp3 gene, also known as Treg-specific demethylated region (TSDR) (126). Thus, those Treg that have a hypomethylated Foxp3 TSDR are more stable as compared to those whose TSDR is hypermethylated $(125,126)$. This also relates to the expression of Foxp3 and its ability to promote expression of Treg associated genes. Accordingly, the activity of DNA methyl transferases in such cells may decide whether phenotypically stable cells will be generated or not. Nrp1 a molecules differentially expressed by tTreg is also involved in stabilization of Foxp3 expression. Signaling induced by ligation of Nrp1 with semaphorin-4a molecule in Treg-enhanced expression of transcription factors such as Foxo1 and Foxo3 to help stabilize Foxp3 expression (23). Eos is another transcription factor that impacts on the stability of Treg, but this effect could be independent of Foxp3 expression (127). Other studies indicate that Treg stability involves post translational modification of Foxp3 and the induction of its alternative splice variants (128). Treg that have enhanced phosphorylated Foxp3 (p-Foxp3) levels are more stable as compared to those that have less or no p-Foxp3 (128-130). Accordingly, phosphatases induced by a highly proinflammatory environment could dephosphorylate Foxp3 in Treg, which then are converted to become pathogenic Th17 cells (129, 130). Another study attributed the metabolic state of Th cells to their function and phenotype (131). Thus, it was shown that glycolysis in Th cells is critical for their conversion to become Treg (131). Enolase I, an enzyme, is induced when cell metabolism is switched to the glycolytic pathway (131). Enolase I plays an essential role by interacting with Foxp 3 regulatory sequences to effect the expression of an alternative splice variant that utilizes exon 2 of Foxp3 (131). However, the mechanisms responsible for stability conferred by alternative splice variants of Foxp3 are not entirely clear, but could relate to their resistance to degradation or the presence of more amino acid residues that can undergo phosphorylation.

Some studies have implicated the role of certain microRNAs in regulating the stability of Treg (132-134). miRNAs are small oligonucleotides that are expressed endogenously and have critical roles in gene expression (132). In general, miRNA 29, 125a, 125b, 155 , and 181 seem to affect differentiation of Th subsets (132). Some miRNAs such as miRNA 181 modulates TCR signaling and its expression alters with the maturation state of T cells (135). miRNA 155 specifically influences differentiation of Treg and Th17 cells which can affect the outcome of inflammatory diseases $(136,137)$.

As differentiation pathways between Treg and Th17 cells are shared, these cells exhibit greater tendency for interconversion. Some investigators have suggested that TGF- $\beta$ induced Tregs as compared to natural Tregs are more likely to acquire a Th17 phenotype. Such cells are more likely to express membrane bound TGF- $\beta$ and in an environment enriched in IL- 6 or other inflammatory molecules, they become Th17 cells (138). Additionally, TGF- $\beta$ induced cells have not established their complete epigenetic landscape and hence are more plastic in nature as compared to natural Treg. The conditions where Th17 cells can also become Foxp3 expressing Treg have not been established as yet, but the Th17 cells change to acquire other phenotypes that include $\operatorname{Th} 1, \operatorname{Th} 2, \operatorname{Tr} 1$, or $\mathrm{T}_{\mathrm{FH}}$. This could occur because of the relative positioning of Foxp 3 and ROR- $\gamma \mathrm{t}$ in a 3-diamensional space in the cell and hence a physical interaction may not occur in Th17 cells as does occur in Treg (139). For establishing plasticity issues unambiguously, fatemapping mice as described in an earlier section are used. Not only mice but also human Treg can become Th17 cells when stimulated with IL-1 $\beta$ and IL-6 (140). In conclusion, the interconversion of Foxp $3^{+}$Treg into Th17 cells is appreciable and well established upon the change of microenvironment but counterconversion of Th17 cells into Foxp $3^{+}$Treg cells is not known currently.

\section{CROSS REGULATION OF TREG AND Th17 CELLS DURING PATHOPHYSIOLOGY OF INFECTIOUS DISEASES}

That Foxp3 is critically involved in the function of Treg has been shown in both humans and mice. A spontaneous mutation comprising a 2-bp insertion in the coding region of Foxp3 gene resulted in a truncated non-functional protein. Mutant mice, known as scurfy mice, developed spontaneous multiorgan inflammatory lesions (141-143). Male mice exhibited a pronounced phenotype as compared to females, suggesting the mutation was $\mathrm{X}$-linked. Crossing scurfy mice with Foxp3 transgenics rescued the phenotype confirming the role of the mutation in disease causation (16). Similarly, patients who had immunodysregulation polyendocrinopathy enteropathy X-linked (IPEX) syndrome exhibited a mutation in the Foxp3 gene and developed autoimmune enteropathy, psoriasiform or eczematous dermatitis, nail dystrophy, and endocrinopathy. IPEX is a rare disease with a strong genetic association (144).

The balancing of response in activity of Treg and Th17 cells can influence the outcome of numerous infectious and noninfectious diseases (108). Whether or not these cells play a role in orchestrating disease due to infections in non-rodent animals is not well established and is suggested based on scanty data, which are often unconfirmed. During infections, the dominant effect of Treg perhaps is not to dampen protective immunity, but 
to prevent collateral tissue damage. In some infections, such as the one caused by Leishmania, Tregs that were induced de novo and recruited to infected sites were specific to pathogen-derived antigens $(14,145)$. Along similar lines, it was demonstrated that parasites (Schistosome) and bacteria (Helicobacter pylori, Mycobacterium, Histoplasma) promoted the peripheral generation of Treg (146-148). A protozoan parasite, Toxoplasma gondii, caused enhanced immunopathological reactions by inhibiting and destabilizing Treg $(14,145)$. Interestingly, destabilized Treg acquired Tbet and produced IFN- $\gamma$ suggesting their conversion into Th1 like cells. In this study, ROR- $\gamma$ t expression by these was not analyzed. Tbet controls the expression of TIM-3 and those Tregs that express TIM-3 were shown to be resistant to apoptosis when ligated with galectin-9 (149). These seemingly contradicting observations could in fact hint the existence of different subtypes of Treg some of which will eventually be eliminated while some remain in animals and serve as dual function. How acute and chronic viral infections signal Treg response has been investigated (46). The outcome of acute infections caused by viruses such as Friend retrovirus, lymphocytic choriomeningitis virus (LCMV), influenza A virus (IAV), West Nile virus (WNV), respiratory syncytial virus (RSV), hepatitis A virus (HAV), and HSV-1 is influenced to a varying degree by Treg and possible Th17 cell responses (150). Acute LCMV infection induced type I interferon that diminished Treg function and as a result anti-viral $\mathrm{CD}^{+}$and $\mathrm{CD}^{+} \mathrm{T}$ cell responses are enhanced (151). Treg also critically influence the outcome of infection by IAV, WNV, RSV, HAV, and HSV-1 (69). In mice infected with IAV intranasally, more Foxp $3^{+}$Treg accumulate in the draining mediastinal LNs (MLNs) suggesting that virus is able to promote Treg responses (152). Mice depleted of Treg developed more severe lesion suggesting Tregs were able to control immunopathological responses. Respiratory influenza infection induced CCR9 ${ }^{+} \mathrm{CD} 4^{+}$ $\mathrm{T}$ helper cell generation in the MLNs. These cells, by responding to CCL25, preferentially migrated to the gut and were responsible for an inflammatory reaction mediated by Th17 cells (153). The antigen specificity and phenotype of migrating $\mathrm{CD}^{+} \mathrm{T}$ cells in the gut are not known. Whether or not the migratory cells by themselves orchestrated gut inflammation, or induced conversion of resident $\mathrm{CD} 4^{+} \mathrm{T}$ cells to become Th17 cells, remains to be elucidated. However, this study indicated that Th17 cells could in fact serve as one of the players of "common mucosal immune axis" and could influence the composition of microbiota in the gut during some infections (153). Another study demonstrated that influenza virus inhibited Th17 mediated control of a secondary bacterial infection to cause pneumonia (154). Therefore, during IAV pathogenesis, the cross play of Treg and Th17 can impact the pathogenesis. During WNV infection in humans, Treg helped control the development of clinical symptoms and fever by preventing tissue damaging inflammatory reactions because asymptomatic individuals had greater numbers of Treg in peripheral blood (155). Similarly, WNV infected mice, depleted of Treg, developed lethal encephalitis suggesting Treg response was protective in nature (155). A specific role of Th17 cells in WNV pathogenesis has not been demonstrated, but encephalitis caused by WNV was not influenced by the Th17 cell response (156). As compared to controls, Treg depleted mice upon RSV infection showed enhanced Th2 responses that led to severe pulmonary immunopathological lesions (157). Most cases of acute HAV infection resolve with efficient viral clearance and innocuous pathological consequences, which could relate to how Treg are signaled (158). HAV directly binds to its cellular receptor 1 (HAVCR1 also known as TIM-1) expressed by Treg and as a result abrogates their function to promote anti-viral $\mathrm{CD} 8^{+} \mathrm{T}$ cell responses. Efficient $\mathrm{CD} 8^{+} \mathrm{T}$ cells then help control virus infection (159). Whether or not Th17 cells play any role in RSV and HAV infection is not clear. The influence of Treg in HSV pathogenesis has been extensively studied by numerous approaches (160-164). Mice that were depleted of Treg prior to HSV infection mounted enhanced primary and memory anti-viral $\mathrm{CD} 8^{+} \mathrm{T}$ cell responses (162) and when Treg were depleted prior to ocular infection with HSV-1 heightened CD4 ${ }^{+} \mathrm{T}$ cell effector response led to an aggravated corneal inflammatory disease, as compared to those mice that had intact Treg responses (163). This observation was followed up in subsequent studies employing adoptive transfer of natural Treg as well as TGF- $\beta$ induced Treg in mice before infection $(161,163)$. Treg recipient mice developed diminished inflammatory lesion as compared to infected controls (161). We observed that ligation of $\mathrm{CD}^{+} \mathrm{T}$ cell expressed sphingosine 1 phosphate receptor (S1P1) by an agonist FTY720 promoted Treg responses $(165,166)$. These converted cells, however, were inclined to acquire a Th17 phenotype when incubated with IL-6 and exhibited an aggressive proinflammatory activity in HSV-1 infected animals (165). IL-6 neutralization diminished lesions of the disease suggesting that the converted cells might be more plastic and in fact more damaging. What stage of infection Treg responses are critical in controlling the disease severity was investigated using a DTR-Foxp3 transgenic mouse model in which Treg could be depleted using diphtheria toxin at different times post-infection (70). The results suggested that Tregs continue to regulate inflammatory responses irrespective of stage when these are depleted and that Treg might in fact be acting both in the DLN during induction phase of response and at inflammatory sites (70). Direct interaction of Treg expressed HVEM and HSV-1-gD glycoprotein provided a partial explanation as to how HSV-1 is able to signal Treg so promptly after infection (167). The role of Th17 cells in HSV-1 induced pathogenesis was also investigated using IL-17R KO mice as well as in mice lacking different subunits of cytokine IL-23 (p19 and p35), a cytokine critically involved in promoting Th17 cell responses $(168,169)$. These studies demonstrated that IL-17 contributed by innate immune cells, $\gamma \delta \mathrm{T}$ cells and Th cells, enhanced the severity of inflammatory lesions. Th17 cells were predominantly involved during the chronic phase of infection, while during the acute phase their contribution was minimal (169). This also suggests that inflammatory milieu in cornea may induce conversion of some accumulated Treg or Th1 cells into a Th17 phenotype. It would be worth investigating whether Th17 cells can further become Treg and how would that influence the lesion severity.

Most chronic viral infections were shown to influence Treg responses and eventually the outcome of chronic infections $(13,46)$. Notably, HIV and HCV are the most prominent chronic viral infections where Treg seems to play a critical role in pathogenesis $(13,46)$. Precise mechanisms how these infections trigger 
Treg responses are not clear, but the microenvironments created could contribute. HIV, HCV, and IAV could all activate latent TGF- $\beta$ to promote Treg and potentially Th17 responses depending on its concentration along with that of other inflammatory cytokines $(43,170,171)$. During HIV infection, Tregs play multiple roles that range from an early abrogation of effector $\mathrm{CD}^{+}$ $\mathrm{T}$ cells to tissue repair during later stages (172). HIV promotes Treg responses by modulating the function of DCs which stimulate Treg generation (173). Tregs, in turn, control the activation of $\mathrm{CD}^{+} \mathrm{T}$ cells to minimize their infection by the virus. Thus, activated $\mathrm{CD}^{+} \mathrm{T}$ cells are more susceptible to HIV infection as compared to those in resting stage (174). TGF- $\beta$ produced by Treg, and probably other cells, promotes collagen deposition in lymphoid organs (175). This poses a problem when the patients are given anti-retroviral therapy and immune reconstitution is required. Thus, the effective space available would be less for immune reconstitution (175). The involvement of Treg in HIV pathogenesis, therefore, is a complex issue and needs more study.

Th17 cells seem to play a crucial role in the pathogenesis of HIV infection as these cells accumulate abundantly in the gutassociated lymphoid tissues (GALT) early after infection (176). Whether the accumulated Th17 cells in GALT originate from Treg or differentiate from naive cells is still to be established. The activated Treg in the gut could contribute to TGF- $\beta$ production and HIV infection could trigger IL- 6 production by innate cells. Th17 cells are known to express surface CD45RO, CCR5, and CXCR4 making them more permissive to HIV infection (177). Infected Th17 cells are cleared by the virus itself, or by cytotoxic $\mathrm{CD}^{+} \mathrm{T}$ cells. As Th17 cells are critical for maintaining the integrity of mucosal barriers, their depletion could disrupt these barriers and initiate generalized immune activation $(178,179)$. The Th17 cells that influence the outcome of HIV infection may not necessarily be specific for viral antigens. The role of Th17 cells was also demonstrated in long-term non-progressers who exhibit pronounced Th17 responses as compared to those who progress rapidly to develop HIV-AIDS. Restoration of Th17 cells in patients undergoing highly active anti-retroviral therapy is an indicator of better prognosis predominantly due to efficient control of bacterial infections by these cells (180). Therefore, a balance of Treg and Th17 cell response may critically influence the pathogenesis of HIV infection.

$\mathrm{HCV}$ and Treg interaction is complicated to investigate, as the responses need to be evaluated in the liver, where disease occurs. This is particularly confounded by the unavailability of a rodent model and the now unavailable chimpanzee being the only reliable animal model to study HCV pathogenesis. What determines the resolution of infection in only $20 \% \mathrm{HCV}$ infected patients is not clearly understood but is thought to be explained by an effective anti-viral $\mathrm{CD}^{+}$and $\mathrm{CD} 4^{+} \mathrm{T}$ cell response $(181,182)$. In those which fail to control infection, some have advocated that an induced Treg response, which blunts the activity of effector T cells, could be the explanation (183). During HCV infection, the cell types that are known to exhibit predominant regulatory activity are $\operatorname{Tr} 1$ cells and possibly CD $8^{+}$Treg in addition to Foxp 3 positive cells as suggested by some studies (170). However, it remains to be evaluated whether Tregs play a beneficial or detrimental role during chronic stages of HCV infection. Th17 cells, owing to their cytokine secretion, are thought to play a predominant role in the repair process leading to fibrosis in the liver and seem not to play a critical role early during HCV infection. Accordingly, patients treated with interferon and ribavirin therapy had decreased Treg responses but minimal effects on Th17 cells were observed (183). The Treg and Th17 cell ratio, however, was skewed toward Th17 cells with a favorable outcome of therapy. How various subsets of Th cells influence HCV pathogenesis remains a controversial issue that merits further evaluation. However, the issue is now less relevant since there is a new highly effective anti-viral that controls HCV infection.

Regulatory T cells, and to a lesser extent Th17 cells, do influence the outcome of various infections in pet animals that include dogs and cats. These animals also serve as models for various infectious and non-infectious diseases. For example, similarities in the pathogenesis of feline immunodeficiency virus (FIV) and HIV make the cat a useful animal model (184). FIV was shown to infect Treg and this made them better suppressors $(113,185)$. FIV infected cats exhibit an early depletion of $\mathrm{CD} 4^{+} \mathrm{T}$ cells and enhanced Treg activity, which in turn compromises anti-viral adaptive immunity. This provides the virus an opportunity to establish a productive infection (186). More recent reports suggest a dysregulation of Treg and Th17 cells during FIV pathogenesis in cats during a systemic infection as well as in the placenta leading to non-viable pregnancies (113). Whether or not a similar situation exists in pregnant women infected with HIV is not known.

The canines genome revealed striking similarities in functionally related genes with humans and single nucleotide polymorphisms have been recently mapped (187). Some shared infections between dogs and humans are beginning to provide new insights in the pathophysiology of diseases (188). Foxp $3^{+}$Treg responses have been studied in canine leishmania infection where a variable response pattern for Treg and Th17 cells was observed in different organs (189). Whether or not interconversion in these cell populations occurs during infection is yet to be explained.

The responsiveness of Treg during infectious diseases in bovines has been investigated (190-192). Mycobacterium paratuberculosis, the causative agent of debilitating Johne's disease and bovine leukemia virus (BLV) induce $\mathrm{CD} 4^{+} \mathrm{T}$ cells that produced IL-10 and those that expressed Foxp3, respectively $(190,192)$. During BLV infections, enhanced Treg responses act to constrain anti-viral immunity and probably cause the pathogen to persist in animals (191). Johne's disease is thought to be orchestrated by Th1 cells of which some cells also produced IL-17 suggesting the plastic nature of these cells. However, as this is mainly a gut associated disease, probably the role of balance between Tregs and Th17 cells would provide better insights into its pathogenesis.

Small ruminants, such as sheep and goats, serve as major livestock for landless laborers and marginal farmers. Which cellular mediators are induced early during the response decides the efficiency of immunity to infections as well as immunization. Major pathogens that infect small ruminants are parasites such as Teladorsagia circumcincta and Haemonchus contortus, which induce an orchestrated response pattern characterized initially by Th1 and during later stages by Th2 and regulatory response $(193,194)$. Whether or not Th17 responses are critical for defense against parasitic infections has not been investigated. As these 
parasites infest gut of these animals, it would be interesting to investigate how a balance of Th17 and Treg is affected. Rinderpest virus is the only pathogen of animals eliminated from the face of earth; however, its close relative pestes des petits ruminantium virus (PPRV) is still a major problem in many parts of the world in ruminants and cause immunosuppression in the host. Both viruses inhibit proliferation of leukocyte in vitro (195). Surprisingly, however, the role of Treg and Th17 during PPRV infection or during vaccination against PPRV has not been investigated and could provide better insights into their pathogenesis and eventually better management practices could be employed.

\section{CONCLUSION}

Enumerable studies performed in rodents and to some extent in humans exposed to or infected with one or more microbes revel an intricate interplay of various subsets of $\mathrm{CD}^{+} \mathrm{T}$ cells which influences the disease outcome. Treg and Th17 response

\section{REFERENCES}

1. Mosmann TR, Cherwinski H, Bond MW, Giedlin MA, Coffman RL. Two types of murine helper T cell clone. I. Definition according to profiles of lymphokine activities and secreted proteins. J Immunol (1986) 136:2348-57.

2. Mosmann TR, Coffman RL. TH1 and TH2 cells: different patterns of lymphokine secretion lead to different functional properties. Annu Rev Immunol (1989) 7:145-73. doi:10.1146/annurev.iy.07.040189.001045

3. Zhu J, Paul WE. CD4 T cells: fates, functions, and faults. Blood (2008) 112:1557-69. doi:10.1182/blood-2008-05-078154

4. Zhu J, Yamane H, Paul WE. Differentiation of effector CD4 T cell populations $\left(^{*}\right)$. Annu Rev Immunol (2010) 28:445-89. doi:10.1146/ annurev-immunol-030409-101212

5. Weaver CT, Harrington LE, Mangan PR, Gavrieli M, Murphy KM. Th17: an effector CD4 T cell lineage with regulatory T cell ties. Immunity (2006) 24:677-88. doi:10.1016/j.immuni.2006.06.002

6. Denning TL, Wang Y, Patel SR, Williams IR, Pulendran B. Lamina propria macrophages and dendritic cells differentially induce regulatory and interleukin 17 - producing T cell responses. Nat Immunol (2007) 8:1086-94. doi:10.1038/ni1511

7. Gershon RK, Kondo K. Cell interactions in the induction of tolerance: the role of thymic lymphocytes. Immunology (1970) 18:723-37.

8. Sakaguchi S, Takahashi T, Nishizuka Y. Study on cellular events in post-thymectomy autoimmune oophoritis in mice. II. Requirement of Lyt-1 cells in normal female mice for the prevention of oophoritis. J Exp Med (1982) 156:1577-86. doi:10.1084/jem.156.6.1565

9. Sakaguchi S, Sakaguchi N, Asano M, Itoh M, Toda M. Immunologic self-tolerance maintained by activated $\mathrm{T}$ cells expressing $\mathrm{IL}-2$ receptor alpha-chains (CD25). Breakdown of a single mechanism of self-tolerance causes various autoimmune diseases. J Immunol (1995) 155:1151-64.

10. Suri-Payer E, Amar AZ, Thornton AM, Shevach EM. CD4+CD25+ T cells inhibit both the induction and effector function of autoreactive $\mathrm{T}$ cells and represent a unique lineage of immunoregulatory cells. JImmunol (1998) 160:1212-8.

11. Thornton AM, Shevach EM. CD4+CD25+ immunoregulatory T cells suppress polyclonal $\mathrm{T}$ cell activation in vitro by inhibiting interleukin 2 production. J Exp Med (1998) 188:287-96. doi:10.1084/jem.188.2.287

12. Belkaid Y. Regulatory $T$ cells and infection: a dangerous necessity. Nat Rev Immunol (2007) 7:875-88. doi:10.1038/nri2189

13. Belkaid Y, Rouse BT. Natural regulatory T cells in infectious disease. Nat Immunol (2005) 6:353-60. doi:10.1038/ni1181

14. Belkaid Y, Tarbell K. Regulatory T cells in the control of host-microorganism interactions $\left(^{*}\right)$. Аnпu Rev Immunol (2009) 27:551-89. doi:10.1146/annurev. immunol.021908.132723 dynamics is beginning to provide new insights into the pathogenesis of various infections. However, there exist a vast gap in our understanding how these cell type are induced, maintained, and interact with each other in animals other than inbred rodents. Such insights could open new avenues of modifying their function to achieve better resolution of infection and mitigate tissue damaging reaction in humans and animals.

\section{AUTHOR CONTRIBUTIONS}

SS compiled information and discussed in context, while BR was involved in editing and logically presenting the information.

\section{FUNDING}

The work was supported by the intramural funding from the Indian Institute of Science Education and Research Mohali to SS and extramural funds from NIH to BR (Grant No AI 063365).

15. Brunkow ME, Jeffery EW, Hjerrild KA, Paeper B, Clark LB, Yasayko SA, et al Disruption of a new forkhead/winged-helix protein, scurfin, results in the fatal lymphoproliferative disorder of the scurfy mouse. Nat Genet (2001) 27:68-73. doi:10.1038/83784

16. Khattri R, Kasprowicz D, Cox T, Mortrud M, Appleby MW, Brunkow $\mathrm{ME}$, et al. The amount of scurfin protein determines peripheral $\mathrm{T}$ cell number and responsiveness. J Immunol (2001) 167:6312-20. doi:10.4049/ jimmunol.167.11.6312

17. Ramsdell F, Ziegler SF. \{FOXP3\} and scurfy: how it all began. Nat Rev Immunol (2014) 14:343-9. doi:10.1038/nri3650

18. Marson A, Kretschmer K, Frampton GM, Jacobsen ES, Polansky JK, MacIsaac $\mathrm{KD}$, et al. Foxp3 occupancy and regulation of key target genes during T-cell stimulation. Nature (2007) 445:931-5. doi:10.1038/nature05478

19. Rudra D, deRoos P, Chaudhry A, Niec RE, Arvey A, Samstein RM, et al. Transcription factor Foxp3 and its protein partners form a complex regulatory network. Nat Immunol (2012) 13:1010-9. doi:10.1038/ni.2402

20. Wu Y, Borde M, Heissmeyer V, Feuerer M, Lapan AD, Stroud JC, et al. FOXP3 controls regulatory $\mathrm{T}$ cell function through cooperation with NFAT. Cel (2006) 126:375-87. doi:10.1016/j.cell.2006.05.042

21. Xie X, Stubbington MJT, Nissen JK, Andersen KG, Hebenstreit D, Teichmann $\mathrm{SA}$, et al. The regulatory $\mathrm{T}$ cell lineage factor Foxp3 regulates gene expression through several distinct mechanisms mostly independent of direct DNA binding. PLoS Genet (2015) 11:e1005251. doi:10.1371/journal.pgen. 1005251

22. Ziegler SF. FOXP3: not just for regulatory T cells anymore. Eur J Immunol (2007) 37:21-3. doi:10.1002/eji.200636435

23. Delgoffe GM, Woo S-R, Turnis ME, Gravano DM, Guy C, Overacre $\mathrm{AE}$, et al. Stability and function of regulatory $\mathrm{T}$ cells is maintained by a neuropilin-1-semaphorin-4a axis. Nature (2013) 501:252-6. doi:10.1038/ nature 12428

24. Weiss JM, Bilate AM, Gobert M, Ding Y, Curotto de Lafaille MA, Parkhurst $\mathrm{CN}$, et al. Neuropilin 1 is expressed on thymus-derived natural regulatory $\mathrm{T}$ cells, but not mucosa-generated induced Foxp3+ T reg cells. J Exp Med (2012) 209(1723-42):S1. doi:10.1084/jem.20120914

25. Yadav M, Louvet C, Davini D, Gardner JM, Martinez-Llordella M, Bailey-Bucktrout S, et al. Neuropilin-1 distinguishes natural and inducible regulatory T cells among regulatory T cell subsets in vivo. J Exp Med (2012) 209(1713-22):S1-19. doi:10.1084/jem.20120822

26. Asano M, Toda M, Sakaguchi N, Sakaguchi S. Autoimmune disease as a consequence of developmental abnormality of a T cell subpopulation. J Exp Med (1996) 184:387-96. doi:10.1084/jem.184.2.387

27. Samy ETE, Wheeler KM, Roper RJ, Teuscher C, Tung KSK. Cutting edge: autoimmune disease in day 3 thymectomized mice is controlled by endogenous disease-specific regulatory T cells. J Immunol (2008) 180:4366-70. 
28. Josefowicz SZ, Lu L-F, Rudensky AY. Regulatory T cells: mechanisms of differentiation and function. Annu Rev Immunol (2012) 30:531-64. doi:10.1146/ annurev.immunol.25.022106.141623

29. Rossjohn J, Gras S, Miles JJ, Turner SJ, Godfrey DI, McCluskey J. T cell antigen receptor recognition of antigen-presenting molecules. Annu Rev Immunol (2015) 33:169-200. doi:10.1146/annurev-immunol-032414-112334

30. Sakaguchi S, Vignali DAA, Rudensky AY, Niec RE, Waldmann H. The plasticity and stability of regulatory T cells. Nat Rev Immunol (2013) 13:461-7. doi:10.1038/nri3464

31. Yin L, Scott-Browne J, Kappler JW, Gapin L, Marrack P. T cells and their eons-old obsession with MHC. Immunol Rev (2012) 250:49-60. doi:10.1111/ imr. 12004

32. Beringer DX, Kleijwegt FS, Wiede F, van der Slik AR, Loh KL, Petersen J, et al. T cell receptor reversed polarity recognition of a self-antigen major histocompatibility complex. Nat Immunol (2015) 16:1153-61. doi:10.1038/ ni.3271

33. Peakman M, Sewell AK. Reversed-polarity Treg cell TCRs provide a shock. Nat Immunol (2015) 16:1105-7. doi:10.1038/ni.3289

34. Purvis HA, Stoop JN, Mann J, Woods S, Kozijn AE, Hambleton S, et al. Low-strength T-cell activation promotes Th17 responses. Blood (2010) 116:4829-37. doi:10.1182/blood-2010-03-272153

35. Rawls JF, Mahowald MA, Ley RE, Gordon JI. Reciprocal gut microbiota transplants from zebrafish and mice to germ-free recipients reveal host habitat selection. Cell (2006) 127:423-33. doi:10.1016/j.cell.2006.08.043

36. Berod L, Friedrich C, Nandan A, Freitag J, Hagemann S, Harmrolfs K, et al. De novo fatty acid synthesis controls the fate between regulatory $\mathrm{T}$ and $\mathrm{T}$ helper 17 cells. Nat Med (2014) 20:1327-33. doi:10.1038/nm.3704

37. Smith PM, Howitt MR, Panikov N, Michaud M, Gallini CA, Bohlooly-Y M, et al. The microbial metabolites, short-chain fatty acids, regulate colonic Treg cell homeostasis. Science (2013) 341:569-73. doi:10.1126/science.1241165

38. Wang C, Yosef N, Gaublomme J, Wu C, Lee Y, Clish CB, et al. CD5L/AIM regulates lipid biosynthesis and restrains Th17 cell pathogenicity. Cell (2015) 163:1413-27. doi:10.1016/j.cell.2015.10.068

39. Scheinecker C, McHugh R, Shevach EM, Germain RN. Constitutive presentation of a natural tissue autoantigen exclusively by dendritic cells in the draining lymph node. J Exp Med (2002) 196:1079-90. doi:10.1084/ jem.20020991

40. Wei S, Kryczek I, Zou W. Regulatory T-cell compartmentalization and trafficking. Blood (2006) 108:426-31. doi:10.1182/blood-2006-01-0177

41. Wheeler KM, Samy ET, Tung KSK. Cutting edge: normal regional lymph node enrichment of antigen-specific regulatory $\mathrm{T}$ cells with autoimmune disease-suppressive capacity. J Immunol (2009) 183:7635-8. doi:10.4049/ jimmunol.0804251

42. Zhang N, Schröppel B, Lal G, Jakubzick C, Mao X, Chen D, et al. Regulatory $\mathrm{T}$ cells sequentially migrate from inflamed tissues to draining lymph nodes to suppress the alloimmune response. Immunity (2009) 30:458-69. doi:10.1016/j.immuni.2008.12.022

43. Amarnath S, Dong L, Li J, Wu Y, Chen W. Endogenous TGF-beta activation by reactive oxygen species is key to Foxp3 induction in TCR-stimulated and HIV-1-infected human CD4+CD25- T cells. Retrovirology (2007) 4:57. doi:10.1186/1742-4690-4-57

44. Koli K, Myllärniemi M, Keski-Oja J, Kinnula VL. Transforming growth factor-beta activation in the lung: focus on fibrosis and reactive oxygen species. Antioxid Redox Signal (2008) 10:333-42. doi:10.1089/ars.2007.1914

45. Li MO, Flavell RA. TGF- $\beta$ : a master of all T cell trades. Cell (2008) 134:392404. doi:10.1016/j.cell.2008.07.025

46. Rouse BT, Sehrawat S. Immunity and immunopathology to viruses: what decides the outcome? Nat Rev Immunol (2010) 10:514-26. doi:10.1038/ nri2802

47. Marie JC, Letterio JJ, Gavin M, Rudensky AY. TGF-betal maintains suppressor function and Foxp3 expression in CD4+CD25+ regulatory T cells. J Exp Med (2005) 201:1061-7. doi:10.1084/jem.20042276

48. Rubtsov YP, Rudensky AY. TGF $\beta$ signalling in control of T-cell-mediated self-reactivity. Nat Rev Immunol (2007) 7:443-53. doi:10.1038/nri2095

49. Wan YY, Flavell RA. "Yin-Yang" functions of transforming growth factor-beta and T regulatory cells in immune regulation. Immunol Rev (2007) 220:199-213. doi:10.1111/j.1600-065X.2007.00565.x

50. von Boehmer H. Oral tolerance: is it all retinoic acid? J Exp Med (2007) 204:1737-9. doi:10.1084/jem.20071251
51. Benson MJ, Pino-Lagos K, Rosemblatt M, Noelle RJ. All-trans retinoic acid mediates enhanced $\mathrm{T}$ reg cell growth, differentiation, and gut homing in the face of high levels of co-stimulation. J Exp Med (2007) 204:1765-74. doi:10.1084/jem.20070719

52. Sun C-M, Hall JA, Blank RB, Bouladoux N, Oukka M, Mora JR, et al. Small intestine lamina propria dendritic cells promote de novo generation of Foxp3 $\mathrm{T}$ reg cells via retinoic acid. J Exp Med (2007) 204:1775-85. doi:10.1084/ jem.20070602

53. Zhou X, Wang W, Yang Y. The expression of retinoic acid receptors in thymus of young children and the effect of all-transretinoic acid on the development of T cells in thymus. J Clin Immunol (2008) 28:85-91. doi:10.1007/ s10875-007-9122-y

54. Vignali DAA, Collison LW, Workman CJ. How regulatory T cells work. Nat Rev Immunol (2008) 8:523-32. doi:10.1038/nri2343

55. Schmierer B, Hill CS. TGF $\beta$-SMAD signal transduction: molecular specificity and functional flexibility. Nat Rev Mol Cell Biol (2007) 8:970-82. doi: $10.1038 / \mathrm{nrm} 2297$

56. Ziegler SF, Buckner JH. FOXP3 and the regulation of Treg/Th17 differentiation. Microbes Infect (2009) 11:594-8. doi:10.1016/j.micinf.2009.04.002

57. Wang X, Zhang Y, Yang XO, Nurieva RI, Chang SH, Ojeda SS, et al. Transcription of IL17 and IL17f is controlled by conserved noncoding sequence 2. Immunity (2012) 36:23-31. doi:10.1016/j.immuni.2011.10.019

58. Fujita-Sato S, Ito $\mathrm{S}$, Isobe $\mathrm{T}$, Ohyama $\mathrm{T}$, Wakabayashi $\mathrm{K}$, Morishita $\mathrm{K}$, et al. Structural basis of digoxin that antagonizes RORgamma t receptor activity and suppresses Th17 cell differentiation and interleukin (IL)-17 production. J Biol Chem (2011) 286(36):31409-17. doi:10.1074/jbc.M111. 254003

59. Hori S, Nomura T, Sakaguchi S. Control of regulatory T cell development by the transcription factor Foxp3. Science (2003) 299:1057-61. doi:10.1126/ science. 1079490

60. Schreiber TH. The use of FoxP3 as a biomarker and prognostic factor for malignant human tumors. Cancer Epidemiol Biomarkers Prev (2007) 16:1931-4. doi:10.1158/1055-9965.EPI-07-0396

61. Shang B, Liu Y, Jiang S, Liu Y. Prognostic value of tumor-infiltrating FoxP3+ regulatory T cells in cancers: a systematic review and meta-analysis. Sci Rep (2015) 5:15179. doi:10.1038/srep15179

62. Weller P, Bankfalvi A, Gu X, Dominas N, Lehnerdt GF, Zeidler R, et al. The role of tumour FoxP3 as prognostic marker in different subtypes of head and neck cancer. Eur J Cancer (2014) 50:1291-300. doi:10.1016/j.ejca. 2014.02.016

63. Bettelli E, Carrier Y, Gao W, Korn T, Strom TB, Oukka M, et al. Reciprocal developmental pathways for the generation of pathogenic effector TH17 and regulatory T cells. Nature (2006) 441:235-8. doi:10.1038/nature04753

64. Fontenot JD, Rasmussen JP, Williams LM, Dooley JL, Farr AG, Rudensky AY. Regulatory $\mathrm{T}$ cell lineage specification by the forkhead transcription factor foxp3. Immunity (2005) 22:329-41. doi:10.1016/j.immuni.2005.01.016

65. Huter EN, Punkosdy GA, Glass DD, Cheng LI, Ward JM, Shevach EM. TGFbeta-induced Foxp3+ regulatory T cells rescue scurfy mice. Eur J Immunol (2008) 38:1814-21. doi:10.1002/eji.200838346

66. Kim JM, Rasmussen JP, Rudensky AY. Regulatory T cells prevent catastrophic autoimmunity throughout the lifespan of mice. Nat Immunol (2007) 8:191-7. doi:10.1038/ni1428

67. Punkosdy GA, Blain M, Glass DD, Lozano MM, O’Mara L, Dudley JP, et al. Regulatory T-cell expansion during chronic viral infection is dependent on endogenous retroviral superantigens. Proc Natl Acad Sci U S A (2011) 108(9):3677-82. doi:10.1073/pnas.1100213108

68. Lahl K, Loddenkemper C, Drouin C, Freyer J, Arnason J, Eberl G, et al. Selective depletion of Foxp3+ regulatory $\mathrm{T}$ cells induces a scurfy-like disease. J Exp Med (2007) 204:57-63. doi:10.1084/jem.20061852

69. Veiga-Parga T, Sehrawat S, Rouse BT. Role of regulatory T cells during virus infection. Immunol Rev (2013) 255:182-96. doi:10.1111/imr.12085

70. Veiga-Parga T, Suryawanshi A, Mulik S, Giménez F, Sharma S, Sparwasser $\mathrm{T}$, et al. On the role of regulatory $\mathrm{T}$ cells during viral-induced inflammatory lesions. J Immunol (2012) 189:5924-33. doi:10.4049/jimmunol.1202322

71. Belkaid Y, Piccirillo CA, Mendez S, Shevach EM, Sacks DL. CD4+CD25+ regulatory $\mathrm{T}$ cells control Leishmania major persistence and immunity. Nature (2002) 420:502-7. doi:10.1038/nature01152

72. Rouvier E, Luciani MF, Mattéi MG, Denizot F, Golstein P. CTLA-8, cloned from an activated $\mathrm{T}$ cell, bearing AU-rich messenger RNA instability 
sequences, and homologous to a Herpesvirus saimiri gene. J Immunol (1993) 150:5445-56.

73. Yao Z, Painter SL, Fanslow WC, Ulrich D, Macduff BM, Spriggs MK, et al. Human IL-17: a novel cytokine derived from T cells. J Immunol (1995) 155:5483-6.

74. Fossiez F, Djossou O, Chomarat P, Flores-Romo L, Ait-Yahia S, Maat C, et al. T cell interleukin-17 induces stromal cells to produce proinflammatory and hematopoietic cytokines. J Exp Med (1996) 183:2593-603. doi:10.1084/ jem.183.6.2593

75. Oppmann B, Lesley R, Blom B, Timans JC, Xu Y, Hunte B, et al. Novel p19 protein engages IL-12p40 to form a cytokine, IL-23, with biological activities similar as well as distinct from IL-12. Immunity (2000) 13:715-25. doi:10.1016/S1074-7613(00)00070-4

76. Ye P, Rodriguez FH, Kanaly S, Stocking KL, Schurr J, Schwarzenberger $\mathrm{P}$, et al. Requirement of interleukin 17 receptor signaling for lung CXC chemokine and granulocyte colony-stimulating factor expression, neutrophil recruitment, and host defense. J Exp Med (2001) 194:519-27. doi:10.1084/ jem.194.4.519

77. Gagliani N, Vesely MCA, Iseppon A, Brockmann L, Xu H, Palm NW, et al. Th17 cells transdifferentiate into regulatory $\mathrm{T}$ cells during resolution of inflammation. Nature (2015) 523:221-5. doi:10.1038/nature14452

78. Miyao T, Floess S, Setoguchi R, Luche H, Fehling HJ, Waldmann H, et al. Plasticity of Foxp3(+) T cells reflects promiscuous Foxp3 expression in conventional $\mathrm{T}$ cells but not reprogramming of regulatory $\mathrm{T}$ cells. Immunity (2012) 36:262-75. doi:10.1016/j.immuni.2011.12.012

79. Komatsu N, Okamoto K, Sawa S, Nakashima T, Oh-hora M, Kodama T, et al. Pathogenic conversion of Foxp3+ T cells into TH17 cells in autoimmune arthritis. Nat Med (2014) 20:62-8. doi:10.1038/nm.3432

80. Overacre AE, Vignali DA. T(reg) stability: to be or not to be. Curr Opin Immunol (2016) 39:39-43. doi:10.1016/j.coi.2015.12.009

81. Varanasi SK, Reddy PBJ, Bhela S, Jaggi U, Gimenez F, Rouse BT. Azacytidine treatment inhibits the progression of herpes stromal keratitis by enhancing regulatory $\mathrm{T}$ cell function. J Virol (2017) 91:e02367-16. doi:10.1128/ JVI.02367-16

82. Cahalan MD, Parker I, Wei SH, Miller MJ. Two-photon tissue imaging: seeing the immune system in a fresh light. Nat Rev Immunol (2002) 2:872-80. doi:10.1038/nri935

83. Phan TG, Bullen A. Practical intravital two-photon microscopy for immunological research: faster, brighter, deeper. Immunol Cell Biol (2010) 88:438-44. doi:10.1038/icb.2009.116

84. Beura LK, Hamilton SE, Bi K, Schenkel JM, Odumade OA, Casey KA, et al. Normalizing the environment recapitulates adult human immune traits in laboratory mice. Nature (2016) 532:512-6. doi:10.1038/nature17655

85. Stappenbeck TS, Virgin HW. Accounting for reciprocal host-microbiome interactions in experimental science. Nature (2016) 534:191-9. doi:10.1038/ nature 18285

86. Sullivan $\mathrm{C}$, Kim $\mathrm{CH}$. Zebrafish as a model for infectious disease and immune function. Fish Shellfish Immunol (2008) 25:341-50. doi:10.1016/ j.fsi.2008.05.005

87. Quintana FJ, Iglesias AH, Farez MF, Caccamo M, Burns EJ, Kassam N, et al. Adaptive autoimmunity and Foxp3-based immunoregulation in zebrafish. PLoS One (2010) 5:e9478. doi:10.1371/journal.pone.0009478

88. Renshaw SA, Trede NS. A model 450 million years in the making: zebrafish and vertebrate immunity. Dis Model Mech (2012) 5:38-47. doi:10.1242/ dmm.007138

89. Lee K-Y, Huang H, Ju B, Yang Z, Lin S. Cloned zebrafish by nuclear transfer from long-term-cultured cells. Nat Biotechnol (2002) 20(8):795-9. doi: $10.1038 /$ nbt721

90. Ma C, Fan L, Ganassin R, Bols N, Collodi P. Production of zebrafish germline chimeras from embryo cell cultures. Proc Natl Acad Sci U S A (2001) 98:2461-6. doi:10.1073/pnas.041449398

91. Poss KD, Keating MT, Nechiporuk A. Tales of regeneration in zebrafish. Dev Dyn (2003) 226:202-10. doi:10.1002/dvdy.10220

92. Siripattarapravat K, Pinmee B, Venta PJ, Chang C-C, Cibelli JB. Somatic cell nuclear transfer in zebrafish. Nat Methods (2009) 6:733-5. doi:10.1038/ nmeth. 1369

93. Auer TO, Del Bene F. CRISPR/Cas9 and TALEN-mediated knock-in approaches in zebrafish. Methods (2014) 69:142-50. doi:10.1016/j.ymeth. 2014.03.027
94. Hruscha A, Schmid B. Generation of zebrafish models by CRISPR/Cas9 genome editing. Methods Mol Biol (2015) 1254:341-50. doi:10.1007/978-14939-2152-2_24

95. Ramakrishnan L. Revisiting the role of the granuloma in tuberculosis. Nat Rev Immunol (2012) 12:352. doi:10.1038/nri3211

96. Swaim LE, Connolly LE, Volkman HE, Humbert O, Born DE, Ramakrishnan L. Mycobacterium marinum infection of adult zebrafish causes caseating granulomatous tuberculosis and is moderated by adaptive immunity. Infect Immun (2006) 74:6108-17. doi:10.1128/IAI.00887-06

97. Collison LW, Vignali DAA. In vitro Treg suppression assays. Methods Mol Biol (2011) 707:21-37. doi:10.1007/978-1-61737-979-6_2

98. Salomon B, Zaragoza B, Chen X, Oppenheim J, Baeyens A, Grégoire S, et al. Human Treg cell suppressive assays. Protoc Exch (2015). doi:10.1038/ protex.2015.078

99. Allan SE, Passerini L, Bacchetta R, Crellin N, Dai M, Orban PC, et al. The role of 2 FOXP3 isoforms in the generation of human CD4+ Tregs. J Clin Invest (2005) 115:3276-84. doi:10.1172/JCI24685

100. Walker MR, Kasprowicz DJ, Gersuk VH, Benard A, Van Landeghen M, Buckner JH, et al. Induction of FoxP3 and acquisition of T regulatory activity by stimulated human CD4+CD25- T cells. J Clin Invest (2003) 112:1437-43. doi:10.1172/JCI19441

101. Das J, Ren G, Zhang L, Roberts AI, Zhao X, Bothwell ALM, et al. Transforming growth factor $\beta$ is dispensable for the molecular orchestration of Th17 cell differentiation. J Exp Med (2009) 206:2407-16. doi:10.1084/jem.20082286

102. Sakaguchi S, Miyara M, Costantino CM, Hafler DA. Foxp $3^{+}$regulatory T cells in the human immune system. Nat Rev Immunol (2010) 10(7):490-500. doi: $10.1038 /$ nri2785

103. Huehn J, Polansky JK, Hamann A. Epigenetic control of FOXP3 expression: the key to a stable regulatory T-cell lineage? Nat Rev Immunol (2009) 9:83-9. doi:10.1038/nri2474

104. Waight JD, Takai S, Marelli B, Qin G, Hance KW, Zhang D, et al. Cutting edge: epigenetic regulation of Foxp3 defines a stable population of CD4+ regulatory $\mathrm{T}$ cells in tumors from mice and humans. J Immunol (2015) 194:878-82. doi:10.4049/jimmunol.1402725

105. Ziegler SF. FOXP3: of mice and men. Annu Rev Immunol (2006) 24:209-26. doi:10.1146/annurev.immunol.24.021605.090547

106. Milpied ÃP, Renand ÃA, Bruneau J, Mendes-Da-Cruz DA, Jacquelin S, Asnafi $\mathrm{V}$, et al. Neuropilin-1 is not a marker of human Foxp3 Treg. Eur J Immunol (2009) 39:1466-71. doi:10.1002/eji.200839040

107. Annunziato F, Cosmi L, Santarlasci V, Maggi L, Liotta F, Mazzinghi B, et al. Phenotypic and functional features of human Th17 cells. J Exp Med (2007) 204:1849-61. doi:10.1084/jem.20070663

108. Tesmer LA, Lundy SK, Sarkar S, Fox DA. Th17 cells in human disease. Immunol Rev (2008) 223:87-113. doi:10.1111/j.1600-065X.2008.00628.x

109. Garden OA, Pinheiro D, Cunningham F. All creatures great and small: regulatory $\mathrm{T}$ cells in mice, humans, dogs and other domestic animal species. Int Immunopharmacol (2011) 11:576-88. doi:10.1016/j.intimp.2010. 11.003

110. Bolzer K, Käser T, Saalmüller A, Hammer SE. Molecular characterisation of porcine Forkhead-box p3 (Foxp3). Vet Immunol Immunopathol (2009) 132:275-81. doi:10.1016/j.vetimm.2009.05.014

111. Lankford S, Petty C, LaVoy A, Reckling S, Tompkins W, Dean GA. Cloning of feline FOXP3 and detection of expression in CD4+CD25+ regulatory T cells. Vet Immunol Immunopathol (2008) 122(1-2):159-66. doi:10.1016/ j.vetimm.2007.11.007

112. Seo KS, Davis WC, Hamilton MJ, Park YH, Bohach GA. Development of monoclonal antibodies to detect bovine FOXP3 in PBMCs exposed to a staphylococcal superantigen. Vet Immunol Immunopathol (2009) 128:30-6. doi:10.1016/j.vetimm.2008.10.292

113. Chumbley LB, Boudreaux CE, Coats KS. Aberrant placental immune parameters in the feline immunodeficiency virus (FIV)-infected cat suggest virus-induced changes in T cell function. Virol J (2013) 10:238. doi:10.1186/1743-422X-10-238

114. Biller BJ, Elmslie RE, Burnett RC, Avery AC, Dow SW. Use of FoxP3 expression to identify regulatory $\mathrm{T}$ cells in healthy dogs and dogs with cancer. Vet Immunol Immunopathol (2007) 116:69-78. doi:10.1016/ j.vetimm.2006.12.002

115. Figueiredo MM, Deoti B, Amorim IF, Pinto AJW, Moraes A, Carvalho CS, et al. Expression of regulatory $\mathrm{T}$ cells in jejunum, colon, and cervical and 
mesenteric lymph nodes of dogs naturally infected with Leishmania infantum. Infect Immun (2014) 82:3704-12. doi:10.1128/IAI.01862-14

116. Kol A, Walker NJ, Nordstrom M, Borjesson DL. Th17 pathway as a target for multipotent stromal cell therapy in dogs: implications for translational research. PLoS One (2016) 11:e0148568. doi:10.1371/journal.pone.0148568

117. Smith WG, Usinger WR, Splitter GA. Bovine con A-induced suppressor cells: generation, macrophage requirements and possible mechanisms of regulatory action. Immunology (1981) 43:91-100.

118. Gerner W, Stadler M, Hammer SE, Klein D, Saalmüller A. Sensitive detection of Foxp3 expression in bovine lymphocytes by flow cytometry. Vet Immunol Immunopathol (2010) 138:154-8. doi:10.1016/j.vetimm.2010.07.009

119. Hoek A, Rutten VPMG, Kool J, Arkesteijn GJA, Bouwstra RJ, Van Rhijn I, et al. Subpopulations of bovine $\mathrm{WC1}(+)$ gammadelta $\mathrm{T}$ cells rather than CD4(+)CD25(high) Foxp3(+) T cells act as immune regulatory cells ex vivo. Vet Res (2009) 40:6. doi:10.1051/vetres:2008044

120. Guzman E, Hope J, Taylor G, Smith AL, Cubillos-Zapata C, Charleston B. Bovine $\gamma \mathrm{d}$ T cells are a major regulatory T cell subset. J Immunol (2014) 193:208-22. doi:10.4049/jimmunol.1303398

121. Arzi B, Mills-Ko E, Verstraete FJM, Kol A, Walker NJ, Badgley MR, et al. Therapeutic efficacy of fresh, autologous mesenchymal stem cells for severe refractory gingivostomatitis in cats. Stem Cells Transl Med (2016) 5:75-86. doi:10.5966/sctm.2015-0127

122. Ohkura N, Kitagawa Y, Sakaguchi S. Development and maintenance of regulatory T cells. Immunity (2013) 38:414-23. doi:10.1016/j.immuni.2013.03.002

123. Delgoffe GM, Bettini ML, Vignali DAA. Identity crisis: it's not just Foxp3 anymore. Immunity (2012) 37:759-61. doi:10.1016/j.immuni.2012.10.012

124. Chen Q, Kim YC, Laurence A, Punkosdy GA, Shevach EM. IL-2 controls the stability of Foxp3 expression in TGF-beta-induced Foxp3+ T cells in vivo. J Immunol (2011) 186:6329-37. doi:10.4049/jimmunol.1100061

125. Zhou X, Bailey-Bucktrout S, Jeker LT, Bluestone JA. Plasticity of CD4(+) FoxP3(+) T cells. Curr Opin Immunol (2009) 21:281-5. doi:10.1016/ j.coi.2009.05.007

126. Ohkura N, Hamaguchi M, Morikawa H, Sugimura K, Tanaka A, Ito Y, et al. T cell receptor stimulation-induced epigenetic changes and Foxp 3 expression are independent and complementary events required for Treg cell development. Immunity (2012) 37:785-99. doi:10.1016/j.immuni.2012.09.010

127. Barbi J, Pardoll D, Pan F. Treg functional stability and its responsiveness to the microenvironment. Immunol Rev (2014) 259:115-39. doi:10.1111/imr.12172

128. Huynh A, DuPage M, Priyadharshini B, Sage PT, Quiros J, Borges CM, et al. Control of PI(3) kinase in Treg cells maintains homeostasis and lineage stability. Nat Immunol (2015) 16:188-96. doi:10.1038/ni.3077

129. Huang G, Wang Y, Shi LZ, Kanneganti T-D, Chi H. Signaling by the phosphatase MKP-1 in dendritic cells imprints distinct effector and regulatory T cell fates. Immunity (2011) 35:45-58. doi:10.1016/j.immuni.2011.05.014

130. Shrestha S, Yang K, Guy C, Vogel P, Neale G, Chi H. Treg cells require the phosphatase PTEN to restrain TH1 and TFH cell responses. Nat Immunol (2015) 16:178-87. doi:10.1038/ni.3076

131. De Rosa V, Galgani M, Porcellini A, Colamatteo A, Santopaolo M, Zuchegna $\mathrm{C}$, et al. Glycolysis controls the induction of human regulatory $\mathrm{T}$ cells by modulating the expression of FOXP3 exon 2 splicing variants. Nat Immunol (2015) 16:1174-84. doi:10.1038/ni.3269

132. Fayyad-Kazan H, Rouas R, Fayyad-Kazan M, Badran R, El Zein N, Lewalle $\mathrm{P}$, et al. MicroRNA profile of circulating CD4-positive regulatory $\mathrm{T}$ cells in human adults and impact of differentially expressed MicroRNAs on expression of two genes essential to their function*. J Biol Chem (2012) 287:9910-22. doi:10.1074/jbc.M111.337154

133. Sethi A, Kulkarni N, Sonar S, Lal G. Role of miRNAs in CD4 T cell plasticity during inflammation and tolerance. Front Genet (2013) 4:8. doi:10.3389/ fgene. 2013.00008

134. Zhou X, Jeker LT, Fife BT, Zhu S, Anderson MS, McManus MT, et al. Selective miRNA disruption in T reg cells leads to uncontrolled autoimmunity. J Exp Med (2008) 205:1983-91. doi:10.1084/jem.20080707

135. Fayyad-Kazan H, Hamade E, Rouas R, Najar M, Fayyad-Kazan M, El Zein N, et al. Downregulation of microRNA-24 and -181 parallels the upregulation of IFN- $\gamma$ secreted by activated human CD4 lymphocytes. Hum Immunol (2014) 75:677-85. doi:10.1016/j.humimm.2014.01.007

136. Banerjee A, Schambach F, DeJong CS, Hammond SM, Reiner SL. MicroRNA-155 inhibits IFN-gamma signaling in CD4+ T cells. Eur J Immunol (2010) 40:225-31. doi:10.1002/eji.200939381
137. Yao R, Ma Y-L, Liang W, Li H-H, Ma Z-J, Yu X, et al. MicroRNA-155 modulates Treg and Th17 cells differentiation and Th17 cell function by targeting SOCS1. PLoS One (2012) 7:e46082. doi:10.1371/journal.pone.0046082

138. Xu L, Kitani A, Fuss I, Strober W. Cutting edge: regulatory T cells induce CD4+CD25-Foxp3- T cells or are self-induced to become Th17 cells in the absence of exogenous TGF-beta. J Immunol (2007) 178:6725-9. doi:10.4049/ jimmunol.178.11.6725

139. Zhang F, Meng G, Strober W. Interactions among the transcription factors Runx1, ROR $\gamma$ t and Foxp3 regulate the differentiation of interleukin 17-producing T cells. Nat Immunol (2008) 9:1297-306. doi:10.1038/ni.1663

140. Ayyoub M, Deknuydt F, Raimbaud I, Dousset C, Leveque L, Bioley G, et al. Human memory FOXP3+ Tregs secrete IL-17 ex vivo and constitutively express the T(H)17 lineage-specific transcription factor RORgamma t. Proc Natl Acad Sci U S A (2009) 106:8635-40. doi:10.1073/pnas.0900621106

141. Blair PJ, Bultman SJ, Haas JC, Rouse BT, Wilkinson JE, Godfrey VL. CD4+CD8- T cells are the effector cells in disease pathogenesis in the scurfy (sf) mouse. J Immunol (1994) 153:3764-74.

142. Godfrey VL, Rouse BT, Wilkinson JE. Transplantation of T cell-mediated, lymphoreticular disease from the scurfy (sf) mouse. Am J Pathol (1994) 145:281-6

143. Kanangat S, Blair P, Reddy R, Daheshia M, Godfrey V, Rouse BT, et al. Disease in the scurfy (sf) mouse is associated with overexpression of cytokine genes. Eur J Immunol (1996) 26:161-5. doi:10.1002/eji.1830260125

144. Powell BR, Buist NR, Stenzel P. An X-linked syndrome of diarrhea, polyendocrinopathy, and fatal infection in infancy. J Pediatr (1982) 100:731-7. doi:10.1016/S0022-3476(82)80573-8

145. Belkaid Y. Role of Foxp3-positive regulatory T cells during infection. Eur J Immunol (2008) 38:918-21. doi:10.1002/eji.200738120

146. Hewitson JP, Grainger JR, Maizels RM. Helminth immunoregulation: the role of parasite secreted proteins in modulating host immunity. Mol Biochem Parasitol (2009) 167:1-11. doi:10.1016/j.molbiopara.2009.04.008

147. Kroetz DN, Deepe GS. CCR5 dictates the equilibrium of proinflammatory IL-17+ and regulatory Foxp3+ T cells in fungal infection. J Immunol (2010) 184:5224-31. doi:10.4049/jimmunol.1000032

148. Lundgren A, Suri-Payer E, Enarsson K, Svennerholm A-M, Lundin BS. Helicobacter pylori-specific CD4+ CD25high regulatory $\mathrm{T}$ cells suppress memory T-cell responses to $\mathrm{H}$. pylori in infected individuals. Infect Immun (2003) 71:1755-62. doi:10.1128/IAI.71.4.1755-1762.2003

149. Sehrawat S, Suryawanshi A, Hirashima M, Rouse BT. Role of Tim-3/galectin-9 inhibitory interaction in viral-induced immunopathology: shifting the balance toward regulators. JImmunol (2009) 182:3191-201. doi:10.4049/ jimmunol.0803673

150. Sehrawat S, Rouse BT. Tregs and infections: on the potential value of modifying their function. J Leukoc Biol (2011) 90:1079-87. doi:10.1189/jlb.0611271

151. Srivastava S, Koch MA, Pepper M, Campbell DJ. Type I interferons directly inhibit regulatory $\mathrm{T}$ cells to allow optimal antiviral $\mathrm{T}$ cell responses during acute LCMV infection. J Exp Med (2014) 211:961-74. doi:10.1084/ jem.20131556

152. Betts RJ, Prabhu N, Ho AWS, Lew FC, Hutchinson PE, Rotzschke O, et al. Influenza A virus infection results in a robust, antigen-responsive, and widely disseminated Foxp3+ regulatory T cell response. J Virol (2012) 86:2817-25. doi:10.1128/JVI.05685-11

153. Wang J, Li F, Wei H, Lian Z-X, Sun R, Tian Z. Respiratory influenza virus infection induces intestinal immune injury via microbiota-mediated Th17 cell-dependent inflammation. J Exp Med (2014) 211:2397-410. doi:10.1084/jem.20140625

154. Kudva A, Scheller EV, Robinson KM, Crowe CR, Choi SM, Slight SR, et al. Influenza A inhibits Th17-mediated host defense against bacterial pneumonia in mice. J Immunol (2011) 186:1666-74. doi:10.4049/jimmunol.1002194

155. Lanteri MC, O'Brien KM, Purtha WE, Cameron MJ, Lund JM, Owen RE, et al. Tregs control the development of symptomatic West Nile virus infection in humans and mice. J Clin Invest (2009) 119:3266-77. doi:10.1172/JCI39387

156. Welte T, Aronson J, Gong B, Rachamallu A, MendellN, Tesh R, etal. V $\gamma 4+$ Tcells regulate host immune response to West Nile virus infection. FEMS Immunol Med Microbiol (2011) 63:183-92. doi:10.1111/j.1574-695X.2011.00840.x

157. Durant LR, Makris S, Voorburg CM, Loebbermann J, Johansson C, Openshaw PJM. Regulatory T cells prevent Th2 immune responses and pulmonary eosinophilia during respiratory syncytial virus infection in mice. J Virol (2013) 87:10946-54. doi:10.1128/JVI.01295-13 
158. Silberstein E, Konduru K, Kaplan GG. The interaction of hepatitis A virus (HAV) with soluble forms of its cellular receptor 1 (HAVCR1) share the physiological requirements of infectivity in cell culture. Virol J (2009) 6:175. doi:10.1186/1743-422X-6-175

159. Manangeeswaran M, Jacques J, Tami C, Konduru K, Amharref N, Perrella O, et al. Binding of hepatitis A virus to its cellular receptor 1 inhibits T-regulatory cell functions in humans. Gastroenterology (2012) 142:1516.e-25.e. doi:10.1053/j.gastro.2012.02.039

160. Rouse BT, Sarangi PP, Suvas S. Regulatory T cells in virus infections. Immunol Rev (2006) 212:272-86. doi:10.1111/j.0105-2896.2006.00412.x

161. Sehrawat S, Suvas S, Sarangi PP, Suryawanshi A, Rouse BT. In vitro-generated antigen-specific CD4+ CD25+ Foxp3+ regulatory T cells control the severity of herpes simplex virus-induced ocular immunoinflammatory lesions. J Virol (2008) 82:6838-51. doi:10.1128/JVI.00697-08

162. Suvas S, Kumaraguru U, Pack CD, Lee S, Rouse BT. CD4+CD25+ T cells regulate virus-specific primary and memory $\mathrm{CD} 8+\mathrm{T}$ cell responses. J Exp Med (2003) 198:889-901. doi:10.1084/jem.20030171

163. Suvas S, Azkur AK, Kim BS, Kumaraguru U, Rouse BT. CD4+CD25+ regulatory $\mathrm{T}$ cells control the severity of viral immunoinflammatory lesions. J Immunol (2004) 172:4123-32. doi:10.4049/jimmunol.172.7.4123

164. Suvas S, Rouse BT. Treg control of antimicrobial T cell responses. Curr Opin Immunol (2006) 18:344-8. doi:10.1016/j.coi.2006.03.005

165. Reddy PBJ, Sehrawat S, Suryawanshi A, Rajasagi NK, Khatri M, Rouse BT. An approach to control relapse of inflammatory lesions after discontinuation of primary therapy. PLoS One (2014) 9:e98051. doi:10.1371/journal. pone.0098051

166. Sehrawat S, Rouse BT. Anti-inflammatory effects of FTY720 against viral-induced immunopathology: role of drug-induced conversion of T cells to become Foxp3+ regulators. J Immunol (2008) 180:7636-47. doi:10.4049/ jimmunol.180.11.7636

167. Sharma S, Rajasagi NK, Veiga-Parga T, Rouse BT. Herpes virus entry mediator (HVEM) modulates proliferation and activation of regulatory $\mathrm{T}$ cells following HSV-1 infection. Microbes Infect (2014) 16:648-60. doi:10.1016/j. micinf.2014.06.005

168. Molesworth-Kenyon SJ, Yin R, Oakes JE, Lausch RN. IL-17 receptor signaling influences virus-induced corneal inflammation. J Leukoc Biol (2008) 83:401-8. doi:10.1189/jlb.0807571

169. Suryawanshi A, Veiga-Parga T, Rajasagi NK, Reddy PBJ, Sehrawat S, Sharma S, et al. Role of IL-17 and Th17 cells in herpes simplex virus-induced corneal immunopathology. J Immunol (2011) 187:1919-30. doi:10.4049/ jimmunol.1100736

170. MacDonald AJ, Duffy M, Brady MT, McKiernan S, Hall W, Hegarty J, et al. CD4 T helper type 1 and regulatory T cells induced against the same epitopes on the core protein in hepatitis C virus-infected persons. J Infect Dis (2002) 185:720-7. doi:10.1086/339340

171. Schultz-Cherry S, Hinshaw VS. Influenza virus neuraminidase activates latent transforming growth factor beta. J Virol (1996) 70:8624-9.

172. Hsieh S-M, Chen M-Y, Pan S-C, Hung C-C, Chang S-C. Aberrant induction of regulatory activity of CD4+CD25+ $\mathrm{T}$ cells by dendritic cells in HIVinfected persons with amebic liver abscess. J Acquir Immune Defic Syndr (2007) 44:6-13. doi:10.1097/01.qai.0000242457.43392.61

173. Losikoff PT, Self AA, Gregory SH. Dendritic cells, regulatory T cells and the pathogenesis of chronic hepatitis C. Virulence (2012) 3:610-20. doi:10.4161/ viru. 21823

174. Moreno-Fernandez ME, Rueda CM, Rusie LK, Chougnet CA. Regulatory T cells control HIV replication in activated T cells through a cAMP-dependent mechanism. Blood (2011) 117:5372-80. doi:10.1182/blood-2010-12-323162

175. Schacker TW, Nguyen PL, Beilman GJ, Wolinsky S, Larson M, Reilly C, et al. Collagen deposition in HIV-1 infected lymphatic tissues and T cell homeostasis. J Clin Invest (2002) 110:1133-9. doi:10.1172/JCI16413

176. Brenchley JM, Paiardini M, Knox KS, Asher AI, Cervasi B, Asher TE, et al. Differential Th17 CD4 T-cell depletion in pathogenic and nonpathogenic lentiviral infections. Blood (2008) 112:2826-35. doi:10.1182/ blood-2008-05-159301

177. El Hed A, Khaitan A, Kozhaya L, Manel N, Daskalakis D, Borkowsky W, et al. Susceptibility of human Th17 cells to human immunodeficiency virus and their perturbation during infection. J Infect Dis (2010) 201:843-54. doi: $10.1086 / 651021$

178. Blaschitz C, Raffatellu M. Th17 cytokines and the gut mucosal barrier. J Clin Immunol (2010) 30:196-203. doi:10.1007/s10875-010-9368-7

179. ElHed A, Unutmaz D. Th17 cells and HIV infection. Curr Opin HIV AIDS (2010) 5:146-50. doi:10.1097/COH.0b013e32833647a8

180. Klatt NR, Brenchley JM. Th17 cell dynamics in HIV infection. Curr Opin HIV AIDS (2010) 5:135-40. doi:10.1097/COH.0b013e3283364846

181. Favre D, Lederer S, Kanwar B, Ma Z-M, Proll S, Kasakow Z, et al. Critical loss of the balance between Th17 and T regulatory cell populations in pathogenic SIV infection. PLoS Pathog (2009) 5:e1000295. doi:10.1371/journal. ppat. 1000295

182. Rouse BT. Regulatory T cells in health and disease. J Intern Med (2007) 262(1):78-95. doi:10.1111/j.1365-2796.2007.01836.x

183. Rowan AG, Fletcher JM, Ryan EJ, Moran B, Hegarty JE, O'Farrelly C, et al. Hepatitis C virus-specific Th17 cells are suppressed by virus-induced TGFbeta. J Immunol (2008) 181:4485-94. doi:10.4049/jimmunol.181.7.4485

184. Yamamoto JK, Sanou MP, Abbott JR, Coleman JK. Feline immunodeficiency virus model for designing HIV/AIDS vaccines. Curr HIV Res (2010) 8:14-25. doi:10.2174/157016210790416361

185. Mexas AM, Fogle JE, Tompkins WA, Tompkins MB. CD4+CD25+ regulatory $\mathrm{T}$ cells are infected and activated during acute FIV infection. Vet Immunol Immunopathol (2008) 126:263-72. doi:10.1016/j.vetimm.2008. 08.003

186. de Parseval A, Chatterji U, Sun P, Elder JH. Feline immunodeficiency virus targets activated CD4+ T cells by using CD134 as a binding receptor. Proc Natl Acad Sci U S A (2004) 101:13044-9. doi:10.1073/PNAS.0404006101

187. Lindblad-Toh K, Wade CM, Mikkelsen TS, Karlsson EK, Jaffe DB, Kamal M, et al. Genome sequence, comparative analysis and haplotype structure of the domestic dog. Nature (2005) 438:803-19. doi:10.1038/nature04338

188. Day MJ. One health: the importance of companion animal vector-borne diseases. Parasit Vectors (2011) 4:49. doi:10.1186/1756-3305-4-49

189. Srivastava S, Shankar P, Mishra J, Singh S. Possibilities and challenges for developing a successful vaccine for leishmaniasis. Parasit Vectors (2016) 9:277. doi:10.1186/s13071-016-1553-y

190. de Almeida DE, Colvin CJ, Coussens PM. Antigen-specific regulatory T cells in bovine paratuberculosis. Vet Immunol Immunopathol (2008) 125:234-45. doi:10.1016/j.vetimm.2008.05.019

191. Coussens PM, Sipkovsky S, Murphy B, Roussey J, Colvin CJ. Regulatory $\mathrm{T}$ cells in cattle and their potential role in bovine paratuberculosis. Comp Immunol Microbiol Infect Dis (2012) 35:233-9. doi:10.1016/j.cimid.2012. 01.004

192. Suzuki S, Konnai S, Okagawa T, Ikebuchi R, Shirai T, Sunden Y, et al. Expression analysis of Foxp3 in T cells from bovine leukemia virus infected cattle. Microbiol Immunol (2013) 57:600-4. doi:10.1111/1348-0421.12073

193. Hassan M, Hanrahan JP, Good B, Mulcahy G, Sweeney T. A differential interplay between the expression of Th1/Th2/Treg related cytokine genes in Teladorsagia circumcincta infected DRB1*1101 carrier lambs. Vet Res (2011) 42:45. doi:10.1186/1297-9716-42-45

194. McRae KM, Stear MJ, Good B, Keane OM. The host immune response to gastrointestinal nematode infection in sheep. Parasite Immunol (2015) 37:605-13. doi:10.1111/pim. 12290

195. Heaney J, Barrett T, Cosby SL. Inhibition of in vitro leukocyte proliferation by Morbilliviruses. J Virol (2002) 76:3579-84. doi:10.1128/ JVI.76.7.3579-3584.2002

Conflict of Interest Statement: The authors declare that the research was conducted in the absence of any commercial or financial relationships that could be construed as a potential conflict of interest.

Copyright (c) 2017 Sehrawat and Rouse. This is an open-access article distributed under the terms of the Creative Commons Attribution License (CC BY). The use, distribution or reproduction in other forums is permitted, provided the original author(s) or licensor are credited and that the original publication in this journal is cited, in accordance with accepted academic practice. No use, distribution or reproduction is permitted which does not comply with these terms. 